\title{
Article \\ Characterization of a Novel Emaravirus Affecting Ash Species (Fraxinus spp.) in Europe
}

\author{
Thomas R. Gaskin ${ }^{1,2}$, Max Tischendorf ${ }^{2}$, Ines Günther ${ }^{2}$, Marius Rehanek ${ }^{2}$, Carmen Büttner ${ }^{2}$ (D) \\ and Susanne von Bargen $2, *$ (D) \\ 1 Brandenburg State Office of Rural Development, Agriculture and Land Consolidation (LELF), \\ Müllroser Chaussee 54, 15236 Frankfurt, Germany; thomas.gaskin@lelf.brandenburg.de \\ 2 Division Phytomedicine, Thaer-Institute of Agricultural and Horticultural Sciences, \\ Humboldt-Universität Zu Berlin, Lentzeallee 55/57, 14195 Berlin, Germany; \\ max.tischendorf@t-online.de (M.T.); i_guenther2015@yahoo.com (I.G.); marius-rehanek@t-online.de (M.R.); \\ carmen.buettner@agrar.hu-berlin.de (C.B.) \\ * Correspondence: Susanne.von.bargen@agrar.hu-berlin.de; Tel.: +49-30-2093-46447
}

Citation: Gaskin, T.R.; Tischendorf,

M.; Günther, I.; Rehanek, M.; Büttner,

C.; von Bargen, S. Characterization of

a Novel Emaravirus Affecting Ash Species (Fraxinus spp.) in Europe. Forests 2021, 12, 1574. https:// doi.org/10.3390/f12111574

Academic Editor: Benedetto T. Linaldeddu

Received: 30 September 2021 Accepted: 11 November 2021 Published: 16 November 2021

Publisher's Note: MDPI stays neutral with regard to jurisdictional claims in published maps and institutional affiliations.

Copyright: (c) 2021 by the authors. Licensee MDPI, Basel, Switzerland. This article is an open access article distributed under the terms and conditions of the Creative Commons Attribution (CC BY) license (https:// creativecommons.org/licenses/by/ $4.0 /)$.

\begin{abstract}
We identified a novel virus in diseased European ash (Fraxinus excelsior) and manna ash (F. ornus) trees exhibiting chlorotic ringspots, mottle and leaf deformation such as curling and shoestring symptoms. High-throughput sequencing (HTS, Illumina RNASeq) of total RNA isolated from diseased leaf material in combination with RT-PCR-based amplification techniques and Sanger sequencing determined five complete genome segments, each encoding a single open reading frame. Sequence analyses of RNA1-RNA5 revealed a genome organization typical for emaraviruses, i.e., (i) conserved and complementary terminal $5^{\prime}$ and $3^{\prime}$ termini of each genome segment (ii) proteins showing significant homologies to the RNA-dependent RNA polymerase (RdRP) encoded by RNA1, the glycoprotein precursor (GPP) encoded by RNA2, the viral nucleocapsid protein (N, RNA3), the movement protein (MP, RNA4), and a protein of $26 \mathrm{kDA}$ (P26, RNA5) highly similar to proteins of unknown function encoded by other emaraviruses. Furthermore, we identified spherical particles (double-membrane bodies, DMB) of different sizes (70-80 nm in diameter) which are typical for emaraviruses exclusively in virus-infected leaf tissue exhibiting mottle and leaf deformation. Sequence comparison and phylogenetic analyses confirmed the identified novel virus as a new member of the genus Emaravirus. We established a species-specific RT-PCR detection protocol and could associate the observed disease symptoms with the infection of the novel emaravirus in F. excelsior and F. ornus. Therefore, we propose the name ash shoestring-associated emaravirus (ASaV). Investigation of ASaV-infected sample trees originating from different locations in Switzerland, Germany, Italy and Sweden provided a wide geographical distribution of the virus in affected ash species. To our knowledge, this is the first confirmation of an emaravirus affecting ash tree species with shoestring symptoms of leaves in Europe.
\end{abstract}

Keywords: forest and urban trees; Fraxinus excelsior; F. ornus; leaf chloroses; high-throughput sequencing; novel emaravirus; shoestring of leaves; street trees

\section{Introduction}

Although virus-like symptoms have long been observed in ash [1,2], no viral agents affecting Fraxinus spp. have to date been studied in detail. The list of plant viruses known to infect ash comprises of generalist species including arabis mosaic virus (ArMV), cherry leaf roll virus (CLRV), tobacco necrosis virus (TNV), tobacco mosaic virus (TMV), tobacco rattle virus (TRV), tomato ringspot virus (ToRSV) and tobacco ringspot virus (TRSV) [3,4]. Our investigations of Fraxinus spp. were instigated by current interest in ash dieback, a disease that has decimated populations of European ash (Fraxinus excelsior L.) across the continent in recent years [5]. Although the disease is primarily thought to be caused by 
the pathogenic fungus Hymenoscyphus fraxineus, the role of other biotic and abiotic stress factors, including viruses, in disease development remains to be investigated.

Ash (Fraxinus spp.; Family: Oleaceae) is a group of broad-leaved, mostly deciduous trees, with both the European ash (F. excelsior) and the manna ash (F. ornus) being native to Europe. Not only do both species have important roles in primary or secondary succession stages in forest ecosystems, they also have a decorative, ornamental use in urban environments [6-8]. Manna ash trees, which are naturally found in the Mediterranean region, are being increasingly trialed in towns and cities due to their drought tolerance in the face of climate change $[9,10]$. Manna ash trees also appear to be less susceptible to ash dieback [11].

The causal agents of virus-suspect symptoms in forestry and urban green spaces were for a long time unknown, their identification only being made possible with advances in molecular biology over the last decades. Although the focus of much research on plant viral pathogens has concerned important agricultural and horticultural crops including fruit trees [3], the increasing application of high throughput sequencing (HTS) technologies is revolutionizing the diagnosis and characterization of plant viruses [12,13]. It is clear that a large uncharacterized forest tree virome is yet to be discovered [14]. HTS technologies have already been successfully used in the identification of a number of novel viruses in trees [15] and also in agricultural crops [16]. For instance, the virome of leaf roll diseased birch trees (Betula spp.) was studied revealing several novel viruses belonging to different genera $[17,18]$. Likewise, novel viruses of the genus Emaravirus were discovered in pedunculate oak (Quercus robur) [19,20] in sycamore maple (Acer pseudoplatanus) [21] and in Eurasian aspen (Populus tremula) [22] by Illumina RNASeq technology, applying total RNA extracted from diseased leaf material.

The genus Emaravirus (Order: Bunyavirales; Family: Fimoviridae) is comprised of viruses with a single-stranded (ss), segmented RNA genome in negative-sense orientation, which are typically transmitted by eriophyid gall mites $[23,24]$. Other characteristics of emaraviruses include conserved, complementary terminal nucleotide sequences, enabling the circularization of genome segments and the formation of a panhandle structure [25], which is thought to be necessary for transcription and replication [26]. Spherical double membrane-bound bodies (DMBs) found in infected cells of host plants are also thought to represent the enveloped virus particles [24]. Since the description of the first member species European mountain ash ringspot-associated emaravirus (EMARaV) and the establishment of the genus Emaravirus [24,26], many other viruses have been assigned to the genus, currently numbering 21 [27]. Most emaraviruses have a narrow host range. Nevertheless, many of them cause economic losses in their respective natural host including important crops, or they could be associated with characteristic disease symptoms in herbaceous plants as well as in deciduous tree species [24]. However, prior to this study, no emaravirus species has been identified infecting Fraxinus spp.

We chose to apply HTS for the identification of viruses associated with observed symptoms in diseased Fraxinus trees. These investigations were complemented by standard, conventional methods of RT-PCR, cloning and Sanger sequencing to obtain the complete sequence of the identified viruses, to develop a reliable detection method and to associate the observed disease symptoms with the novel ash pathogen. Here, we report on the identification of a novel emaravirus in Fraxinus spp. and provide the first information towards an in-depth biological characterization of the virus including genome structure, phylogenetic analyses and a first assessment of genetic variability. Such information not only contributes to our knowledge on emaraviruses, but is also essential for determining the significance of the virus, evaluating ecological and economic impacts and developing possible management strategies in the future. 


\section{Materials and Methods}

\subsection{Plant Material and RNA Extraction}

Following observations of suspected virus symptoms in F. excelsior in Switzerland, other symptomatic trees, including manna ash (Fraxinus ornus L.), were found at different geographical locations across Europe. These included trees in both managed semi-natural ecosystems and urban environments, independent of latitude and elevation. Affected ash exhibited chlorotic ringspots, mottle and leaf deformations, ranging from curling to a severe narrowing of the leaflets termed shoestring. Cauliflower galls-growths caused by the gall mite Aceria fraxinivora were also recorded on some of the symptomatic trees. A selection of symptoms documented in F. excelsior from Basel, Switzerland in 2016 and F. ornus from Hamburg, Germany in 2018 are shown in Figure 1.
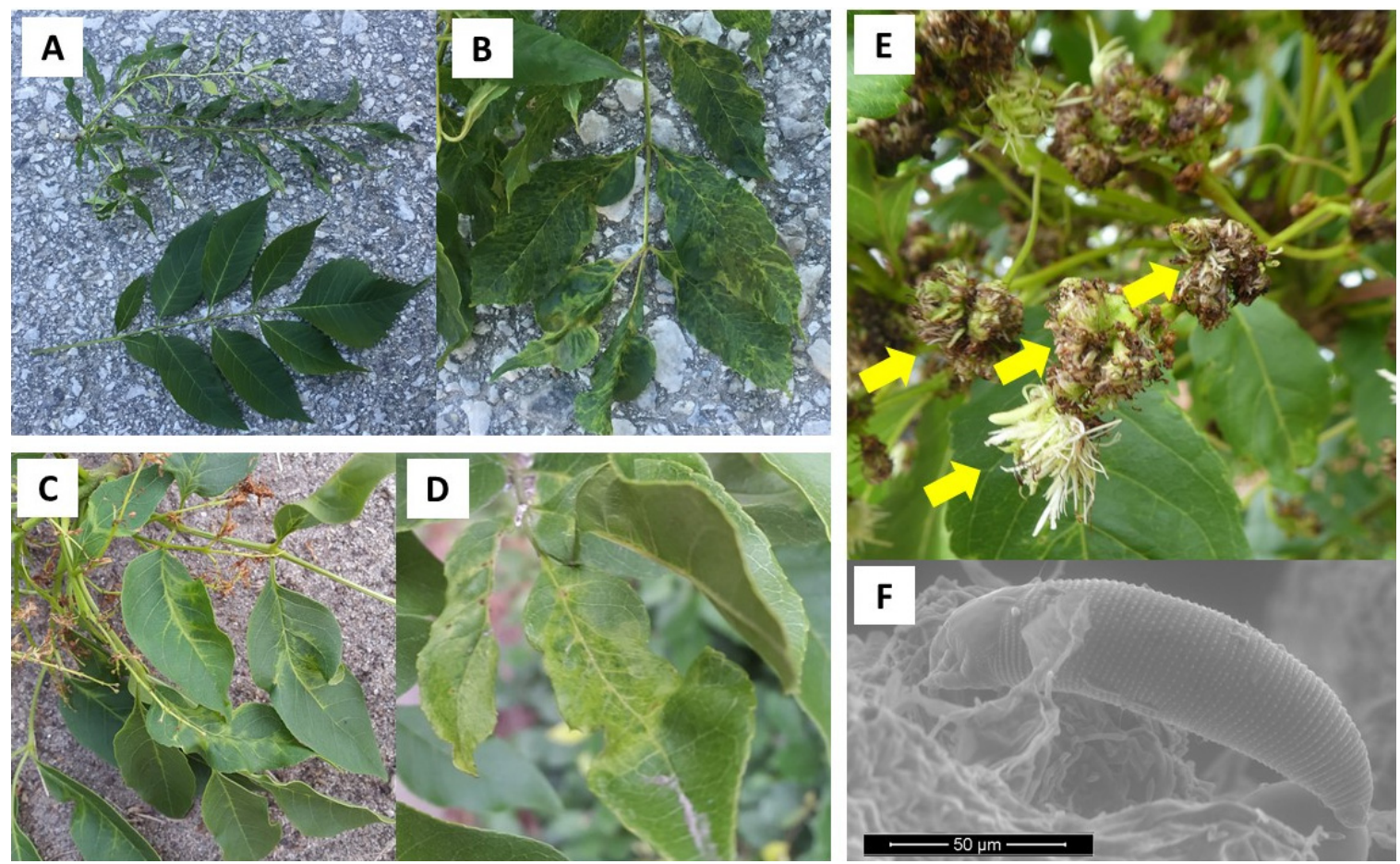

Figure 1. Leaf symptoms observed in virus-infected Fraxinus spp. and associated gall mites. (A) Shoestring (top) in comparison to normal shaped F. excelsior leaf (bottom), (E552628) (B) Leaf of F. excelsior (E55270) exhibiting deformation chlorotic lines and mottle, (C) F. ornus (E57322) leaves with vein yellowing and shoestring, (D) deformed leaflets of $F$. ornus (E57335) exhibiting chlorotic ringspots and mottle. Cauliflower galls (yellow arrows) observed in the F. ornus canopy (E). Electron microscopic image of gall mite A. fraxinivora prepared from a cauliflower gall $(\mathbf{F})$.

For HTS analyses, total RNA was extracted as described by Mielke and Mühlbach 2007 [26], excluding the phenol/chloroform step, from leaf material collected in 2016 from two Fraxinus excelsior trees (E55262 and E55268, Basel, Switzerland), displaying viruslike disease symptoms thought to be caused by virus infection. Leaf samples displayed chlorotic ringspots, lines and leaf deformations including a severe narrowing of the leaflets, termed shoestring. RNA was also extracted from a second set of pooled leaf samples (E57321-E57325, E57328-E57330, E57335-E57337, E57339) originating from 12 Fraxinus ornus trees (Hamburg, Germany, sampled in 2018) displaying identical symptoms as the ash trees in Basel. The same total RNA extraction method was also applied to the following samples collected from locations across Europe between 2016 and 2019: E55270 (F. excelsior, Basel, Switzerland, sampled 2016), E56800, E56802-E56814, E56818, E56820 (F. excelsior, Dalby Söderskog, Sigtuna, Bromma, Vreta, Sweden, sampled 2017), E57294, E57478, E57480, E57481 (F. excelsior, Hamburg, Germany, sampled 2018), E57298, E57299, E57331, E57332, E57326, E57338, E57482, E57483, E57485-E57495, E57515-E57519, (F. ornus 
Hamburg, Germany, sampled 2018), E57471, E57472 (F. ornus Bolzano, Italy, sampled 2018), E57455, E57456-E57459, E57465-E57469 (F. excelsior, Sweden, sampled 2018), E57340 (F. excelsior Crans Montana, Switzerland, sampled 2018), E58222, E58223, E58235-E58246 (F. excelsior Krusenstern Herrgard, Hällekis Blomberg, Västerplana, Sweden sampled 2019), E58250 (F. excelsior Berlin, Germany, sampled 2019), E58592-E58598 and E58047 (F. ornus Hamburg, Germany, sampled 2019). Samples were collected from trees in urban locations, with both symptomatic and asymptomatic leaves being collected for analysis. Eleven F. ornus samples (E57504-E57514) were also collected in 2018 in Hamburg from symptomatic and asymptomatic trees at a local tree nursery and the same methodology was applied.

\subsection{HTS of Leaf Material from Diseased Fraxinus spp.}

Equimolar ratios of total RNA extracted from F. excelsior samples E55262 and E55268 were pooled and $60 \mu \mathrm{g}$ was subjected to cDNA-synthesis with random hexamer primer (Biolegio B.V., Nijmegen, The Netherlands) as described previously by Bandte et al. [20] and von Bargen et al. [28]. The second sample pool was generated in the same way using total RNA extracted from leaf samples of 12 F. ornus trees (E57321-E57325, E57328-E57330, E57335-E57337, E57339). Both sample pools were further prepared for high-throughput Illumina RNA sequencing (HTS) as outlined in the paper by von Bargen et al. [28]. A standard paired-end 125-bp library (Nextera XT) was prepared from $140 \mathrm{ng}$ of ds cDNA generated from the F. excelsior and $410 \mathrm{ng}$ of ds cDNA of the F. ornus sample pool, respectively, by the sequencing company BaseClear B.V. (Leiden, The Netherlands) and sequenced on a HiSeq2500 machine (Illumina, Illumina Solutions, Berlin, Germany). Quality trimming of raw data and de novo assembly into scaffolds was performed according to an in-house protocol of Baseclear. This protocol included generation of FASTQ sequence files with the Illumina Casava pipeline version 1.8.3 (Illumina Solutions, Berlin, Germany). Reads containing PhiX control signal were removed and reads containing partial adapter sequences up to a minimum read length of $50 \mathrm{bp}$ were clipped. De novo assembly was carried out with CLC Genomics Workbench version 9.5.1 (Qiagen GmbH, Hilden, Germany) after trimming off low-quality bases of FASTQ sequences. Misassembles and nucleotide disagreements between Illumina generated data and the contig sequences were corrected with Pilon version 1.11 [29]. Scaffolds with a minimum length of 300 nucleotides were generated with the SSPACE Premium scaffolder version 2.3 [30] and gapped regions were closed when possible, using GapFiller version 1.10 [31].

Viral sequences in the datasets were identified by blastx search of the assembled sequence scaffolds against the non-redundant protein sequence database provided by the National Center for Bioinformatic Information (NCBI) as described previously [22]. All scaffolds relating to plant viruses were aligned to reference genomes in BioEdit, version 7.0.5.3 [32] using the integrated Clustal-W option.

\subsection{Determination of the Complete Genome of the Novel Virus}

Preliminary analysis of HTS sequence data identified scaffolds relating to five different genomic RNAs of virus species belonging to the genus Emaravirus. In order to determine the complete sequence of the novel virus, full-length RT-PCR was performed, applying the PDAP213 primer [33] using total RNA prepared from F. excelsior leaves (E55270) displaying the shoestring symptom. Full-length PCR products were cloned and sequenced as described in von Bargen et al. [28] and Rehanek et al. [19] with at least two identical fragments being required for sequence confirmation. As amplification of the complete RNA1 could not be achieved, eight primer pairs producing overlapping fragments spanning the complete genome segment were constructed based on original HTS scaffolds (Table S1, Supplementary Information). PCR products of the viral RNA1 of sample E55270 were generated by RT-PCR. Following cDNA synthesis from 1-3 $\mu$ g of total RNA using random hexamer oligonucleotides (Biolegio $\mathrm{GmbH}$, Nijmegen, The Netherlands), RT-PCR was performed in a $50 \mu \mathrm{L}$ reaction mixture of $37.5 \mu \mathrm{L}$ MilliQ-H2O, $10 \mu \mathrm{L} 5 \times$ HiFi Reaction buffer, $1 \mu \mathrm{L}$ dNTPs (10 mM each), $0.5 \mu \mathrm{L}$ forward and reverse primers (50 $\mu \mathrm{M}), 1$ unit (U) 
velocity polymerase (Bioline/Meridian Biosciences, Cincinnati, OH, USA) and $1 \mu \mathrm{L}$ cDNA. Cycling conditions were as follows: initial denaturation at $94^{\circ} \mathrm{C}$ for $2 \mathrm{~min}$, followed by 30 to 35 cycles of denaturation at $94{ }^{\circ} \mathrm{C}$ for $20 \mathrm{~s}$, annealing at $55^{\circ} \mathrm{C}$ for $20 \mathrm{~s}$ and elongation at $72{ }^{\circ} \mathrm{C}$ for $15-30 \mathrm{~s}$ (adjusted for fragment length according to manufactures instructions). Following their purification using the MSB Spin PCRapace kit (Invitek Molecular, Berlin, Germany), generated products were sequenced from both directions with fragment-specific primers (Macrogen Europe B.V., Amsterdam, The Netherlands).

A modified RT-PCR protocol, a tailing PCR, was employed to confirm terminal ends of the RNA1 and 2. Following cDNA synthesis as described above, enzymatic degradation of residual RNA was achieved by adding 3 units (U) of RNase H (Thermo Fisher Scientific, Waltham, MA, USA) to $40 \mu \mathrm{L}$ of the cDNA and incubating the samples at $37^{\circ} \mathrm{C}$ for $30 \mathrm{~min}$. A poly-A (adenine) tail was added to $3^{\prime} \mathrm{cDNA}$ ends with the help of $1 \mathrm{U}$ of terminal transferase (Thermo Fisher Scientific, Waltham, MA, USA). The poly-A cDNA was then purified (MSB Spin PCRapace kit, Invitek Molecular, Berlin, Germany) and used as a template for PCR, utilizing two virus-specific primers in the form of a semi-nested PCR, allowing the amplification of a specific terminal end of a particular genome segment. Primer sets and PCR conditions for the tailing PCR with velocity polymerase are provided in the Supplementary Information (Table S1). PCR products of expected size were cloned in E. coli (XL1blue, MRF', Thermo Fisher Scientific, Waltham, MA, USA) using the CloneJET PCR cloning kit (Thermo Fisher Scientific, Waltham, MA, USA) and 2-5 clones were sequenced (Macrogen Europe B.V., Amsterdam, The Netherlands) to determine the terminal ends of viral RNA1 and RNA2.

All HTS- and RT-PCR-generated sequence data were edited, aligned and translated in BioEdit, version 7.0.5.3 [32]. The single open reading frame (ORF) of each RNA segment was located and translated using the NCBI ORF finder (https:/ / www.ncbi.nlm.nih.gov/ orffinder (accessed on 21 March 2021)). A comparison of the RNA1-5 encoded proteins of the novel virus with corresponding proteins of classified and putative members of the genus Emaravirus was performed using the Sequence Identity Matrix function of BioEdit [32]. Phylogenetic analyses were performed using MUSCLE [34] to align the RNA1 and RNA3 encoded amino acid sequences of the novel virus identified in F. excelsior (E55270) and F. ornus (HTS data) with corresponding sequences of selected putative and classified emaraviruses. Phylogenetic trees were constructed using neighbor-joining methodology in Geneious prime 2019.1.1 (Biomatters Ltd., Auckland, New Zealand).

\subsection{Detection of the Novel Virus and Association with Disease Symptoms in Fraxinus spp.}

Six specific primer pairs (Table 1) targeting the five genome segments of the novel virus discovered in diseased ash were designed using HTS sequence information from the original pooled sample (E55262 and E55268). The specificity of each segment-specific primer set was evaluated using total RNA extracted from symptomatic and asymptomatic F. excelsior leaves and leaf material of four other deciduous tree species, known to be infected with putative emaraviruses: common oak ringspot-associated virus (CORaV)-infected Quercus robur [19,20], maple mottle-associated virus (MaMaV)-infected Acer pseudoplatanus [21], fig mosaic virus (FMV)-infected Ficus carica [35] and aspen mosaic-associated virus (AsMaV)infected Populus tremula [22].

Following total RNA extraction, first strand cDNA synthesis was performed using random hexamer oligonucleotides. Two $\mu \mathrm{L}$ of the primer $(50 \mu \mathrm{M})$ was added to $1 \mu \mathrm{g}$ of RNA and topped up with to $12.5 \mu \mathrm{L}$ with MilliQ- $\mathrm{H}_{2} \mathrm{O}$. After 5 min of incubation at $70{ }^{\circ} \mathrm{C}$ and $5 \mathrm{~min}$ on ice, $4 \mu \mathrm{L}$ of $5 \times$ RevAid buffer, $2 \mu \mathrm{L}$ of dNTPs (10 mM each), $0.5 \mu \mathrm{L}$ of RiboLock RNase Inhibitor $(40 \mathrm{U} / \mu \mathrm{L})$ and $1 \mu \mathrm{L}$ of RevertAid Reverse Transcriptase (200 U/ $\mu \mathrm{L}$ ), (all Thermo Fisher Scientific, Waltham, MA, USA)) were added to the mixture. The mixture was incubated at $25^{\circ} \mathrm{C}$ for $10 \mathrm{~min}$ followed by $60 \mathrm{~min}$ at $42{ }^{\circ} \mathrm{C}$ and $10 \mathrm{~min}$ at $70^{\circ} \mathrm{C}$. Quality of cDNA was checked using plant nad5-PCR, in line with Menzel et al. [36], as an internal control to avoid false negatives. A $25 \mu \mathrm{L}$ PCR mixture for detection of the novel virus was prepared with: $18.5 \mu \mathrm{L}$ of $\mathrm{MilliQ}-\mathrm{H}_{2} \mathrm{O}, 1 \mu \mathrm{L}$ of $\mathrm{MgCl}_{2}(50 \mathrm{mM}), 2.5 \mu \mathrm{L}$ 
of $10 \times$ PCR buffer (without $\mathrm{MgCl}_{2}$ ), $0.5 \mu \mathrm{L}$ of dNTPs (10 mM each), $0.25 \mu \mathrm{L}$ of both forward and reverse primers $(50 \mathrm{mM}), 0.125$ units of DreamTaq polymerase (Thermo Fisher Scientific, Waltham, MA, USA) and $1 \mu \mathrm{L}$ of cDNA. PCR cycling conditions were as follows: initial denaturation at $94{ }^{\circ} \mathrm{C}$ for 2 min followed by 35 cycles of denaturation at $94{ }^{\circ} \mathrm{C}$ for $30 \mathrm{~s}$, annealing at $55^{\circ} \mathrm{C}$ for $30 \mathrm{~s}$, elongation at $72{ }^{\circ} \mathrm{C}$ for $30 \mathrm{~s}$ and a final elongation at $72{ }^{\circ} \mathrm{C}$ for $2 \mathrm{~min}$.

Table 1. Segment-specific primer sets for the detection of the novel virus identified in diseased Fraxinus spp.

\begin{tabular}{cccc}
\hline $\begin{array}{c}\text { Genome } \\
\text { Segment }\end{array}$ & Primer & Sequence 5'-3' & $\begin{array}{c}\text { Amplicon } \\
\text { Size (bp) }\end{array}$ \\
\hline \multirow{2}{*}{ RNA1 } & S104-684F & GGTGACAACTATACAAGATCAG & \\
& S152-97R & CTAAATCATTGGCATATACACC & 429 \\
& S50-1081F & GTATGAAAGGGATGATTCAGATC & 289 \\
& S294-146R & ATAGTCTATTGCTGGTGTGGAG & \\
\hline \multirow{2}{*}{ RNA2 } & S68-933F & CAGCAACTATTTGTGGTTCATG & \multirow{2}{*}{243} \\
& S71-187R & CATTTGTCCAGTGTACACATGG & \\
\hline \multirow{2}{*}{ RNA3 } & S55-579F & AAGATCTGCTCCTGATCCTGC & \multirow{2}{*}{342} \\
& S55-920R & CTGGTTGTCCCAATATCTCTGG & \multirow{2}{*}{498} \\
\hline \multirow{2}{*}{ RNA4 } & S65-99F & CAATGGCATAGAAAGCATCACT & \multirow{2}{*}{401} \\
& S65-596R & GGTAATGTCTTCCATGATACATC & \\
\hline \multirow{2}{*}{ RNA5 } & S164-41F & GACAATTAGAGAGGCTCATGA & \\
& S164-441R & CATGTACAGTTGATACCACAG & \\
\hline
\end{tabular}

Fifty-two F. excelsior and 57 F. ornus leaf samples, collected during the vegetation periods between 2016 and 2019, were investigated for the presence of the novel virus. Samples originated from urban locations in Germany, Northern Italy, Southern Sweden and Switzerland as listed in the Section 2.1. Suspected virus symptoms were documented and all samples were tested by RT-PCR, applying the virus segment-specific primer sets (Table 1). Twelve samples from both F. excelsior and F. ornus displayed no observable symptoms of virus infection.

\subsection{Variability Analysis of Virus Variants}

Genetic variability in the novel virus was investigated using partial PCR products generated during the study. Fifty-two RNA3 (18 from F. excelsior and 34 from F. ornus), 17 RNA4 (10 F. excelsior and 7 F. ornus) and 49 RNA5 (17 F. excelsior and 32 F. ornus) PCR amplicons were purified (MSB Spin PCRapace kit, Invitek Molecular, Berlin, Germany), bidirectionally sequenced (Macrogen Europe B.V., Amsterdam, The Netherlands) and aligned in BioEdit. Sequences were trimmed to be in-frame and translated. Partial RNA3-5 sequences were $297 \mathrm{nt}$ (99 aa), $453 \mathrm{nt}$ (151 aa) and $357 \mathrm{nt}$ (119 aa) in length, respectively, with all being found within the coding region of the respective genome segments. Pairwise sequence comparisons were performed in MEGA-X, version 10.0.5 [37] using the distance estimation function, applying the maximum composite likelihood model to nucleotide sequences and the equal input model to amino acid sequences. The standard error of the mean genetic distance was calculated for each set of values.

\subsection{Electron Microscopic Studies}

Leaves from a virus-infected ash tree (F. excelsior, E57075) exhibiting chlorotic line pattern and mottle accompanied by leaf deformation such as curling and shoestring were compared with asymptomatic leaf tissue from a healthy ash tree (E57079) sampled in Crans Montana in September 2017. Specimens were kept in sterile water until sample preparation. For this purpose, fragments of symptomatic or asymptomatic petiole and leaf blade were pre-fixed using a paraformaldehyde (2\%) glutaraldehyde $(3 \%)$ solution at $\mathrm{pH} 7.0$ (0.07 M PIPES buffer) for $3 \mathrm{~h}$ at room temperature and descending atmospheric pressure. 
Subsequently, samples were washed three times with PIPES buffer (0.07 M, pH 7.0) and post-fixed with $1 \% \mathrm{OsO} 4$ in $0.07 \mathrm{M}$ PIPES buffer for $90 \mathrm{~min}$. Fixed samples were rinsed twice with $0.07 \mathrm{M}$ PIPES buffer and stored at $4{ }^{\circ} \mathrm{C}$ until dehydration and infiltration with the Embed 812 resin (Electron Microscopy Sciences, Hatfield, PA, USA). Prior to the infiltration with the resin, samples were dehydrated by incubating the samples on growing concentrations of ethanol (30-50-70-95-100\% ethanol) for $10 \mathrm{~min}$ and continuous agitation in the tissue processor Leica EM TP (Leica Microsystems, Heerbrugg, Switzerland). The ethanol was then replaced by propylene oxide for $30 \mathrm{~min}$ with continuous agitation, and the propylene oxide was subsequently replaced by the Embed 812 resin overnight with gentle agitation. To ensure the infiltration of the resin, samples were incubated for $2 \mathrm{~h}$ under vacuum (400 bars). Polymerization of the resin took place at $60{ }^{\circ} \mathrm{C}$ for $48 \mathrm{~h}$. Infiltrated samples were then thin cut $(0.08 \mu \mathrm{m})$ and stained with $2 \%$ uranyl acetate followed by lead citrate, according to Reynolds [38]. Thin sections were observed with a transmission electron microscope CM10 (Philips, Hillsboro, OR, USA) with a Mega View II camera.

\section{Results}

3.1. Identification and Assembly of the Complete Genome of a Novel Virus in Shoestring-Diseased Fraxinus spp.

In the HTS datasets obtained by RNAseq from pooled leaf samples of two different ash species (F. excelsior and F. ornus) exhibiting chlorotic ringspots and lines, vein yellowing and leaf deformations such as curling and shoestring (Figure 1), we could identify several scaffolds relating to five different genome segments of the plant infecting emaraviruses (Table 2). The first HTS dataset (194 MB), originating from two diseased F. excelsior trees (Basel, Switzerland), yielded a total of 1,657,082 reads (1,199,175 mapped reads) leading to 599 assembled scaffolds with a maximum length of 7048 nucleotides. Six scaffolds produced significant hits in blastx to the RNA1 of Actinidia emaravirus 2 (AcV-2), Pigeonpea sterility mosaic emaravirus-2 (PPSMV-2), and FMV, respectively. Two scaffolds related to RNA2 of PPSMV-2, one scaffold showed 99\% sequence identity to the coding region of RNA3 of the putative novel emaravirus pea-associated virus, while two other scaffolds exhibited sequence identities of $77 \%$ to the RNA4-encoded movement protein (MP) of FMV and $46 \%$ with the $\mathrm{P} 6$ of AcV-2, respectively. All identified scaffolds relating to emaraviruses were represented by $2.57 \%$ of the total reads in the HTS pool from F. excelsior. The second HTS dataset was generated from approximately three times the amount of ds cDNA of pooled symptomatic leaf material of 12 diseased F. ornus trees (Hamburg, Germany) as compared to the first RNASeq run from the F. excelsior sample pool. This allowed a deeper sequencing yielding in $896 \mathrm{MB}(6,633,156$ total reads, 5,930,967 mapped reads) assembled into 10,568 scaffolds with a maximum length of 37,836 nucleotides. As shown in Table 2, we found five scaffolds relating to emaravirus-encoded protein sequences encoded by RNA1-RNA4, and RNA6 of the aforementioned emaraviruses, respectively. Although the overall percentage of total reads $(0.23 \%)$ of these five scaffolds is lower than in the first HTS dataset, the mean coverage of each scaffold was considerably higher in the HTS dataset from F. ornus. Therefore, it was possible to assemble five nearly complete genome segments of a novel virus relating to emaraviruses.

Sequence comparison at the nucleotide level of overlapping regions of all obtained scaffolds identified in F. ornus and F. excelsior showed high sequence identities between 95.3-97.1\% (RNA1), 95.0-96.2\% (RNA2), 97.4\% (RNA3), 95.0\% (RNA4) and 96.8\% (RNA5), respectively, thus confirming that the same virus is present in both datasets derived from European ash and manna ash, respectively (data not shown). Identified scaffolds originating from the F. excelsior and F. ornus HTS datasets, which relate to emaraviral sequences, were deposited in the European Nucleotide Archive (ENA) and are available under the study number: PRJEB46740 (Accession numbers OU466864-OU466879). Scaffolds producing significant hits in blastx with sequences from other viral genera with plant infecting viruses were not found in either dataset. 


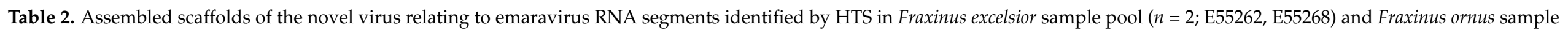

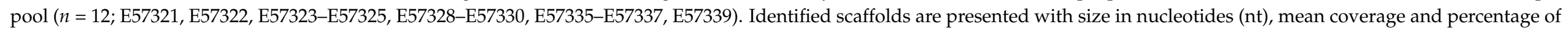
mapped reads. Best matches in blastx search including query coverage, E value and sequence identity are given for each scaffold.

\begin{tabular}{|c|c|c|c|c|c|c|c|c|}
\hline $\begin{array}{c}\text { RNA } \\
\text { Genomic } \\
\text { Segment }\end{array}$ & $\begin{array}{l}\text { Scaffold } \\
\text { Number }\end{array}$ & Size (nt) & $\begin{array}{l}\% \text { Total } \\
\text { Reads }\end{array}$ & $\begin{array}{c}\text { Mean } \\
\text { Coverage }\end{array}$ & Best Match in Blastx (Accession Number) & $\begin{array}{c}\text { Query } \\
\text { Coverage (\%) }\end{array}$ & E Value & $\begin{array}{c}\text { Sequence } \\
\text { Identity (\%) }\end{array}$ \\
\hline \multicolumn{9}{|c|}{ Fraxinus excelsior } \\
\hline \multirow[t]{6}{*}{ RNA1 } & S34 & 1455 & 0.37 & 6.54 & RdRP, Actinidia emaravirus 2 (QEE82886.1) & 99 & 0.0 & 73.76 \\
\hline & S50 & 1195 & 0.31 & 7.40 & RdRP, Actinidia emaravirus 2 (QEE82886.1) & 99 & 0.0 & 87.12 \\
\hline & S104 & 797 & 0.20 & 5.27 & RdRP, Actinidia emaravirus 2 (QEE82886.1) & 95 & $1 \times 10^{-102}$ & 63.53 \\
\hline & S152 & 661 & 0.17 & 6.33 & RdRP, Pigeonpea sterility mosaic emaravirus 2 (QBA83607.1) & 94 & $3 \times 10^{-116}$ & 85.58 \\
\hline & S206 & 548 & 0.14 & 5.83 & RdRP, Actinidia emaravirus 2 (QEE82886.1) & 99 & $6 \times 10^{-90}$ & 75.41 \\
\hline & S294 & 465 & 0.12 & 7.54 & RdRP, Fig mosaic emaravirus (QBH72678.1) & 99 & $1 \times 10^{-86}$ & 87.66 \\
\hline \multirow[t]{2}{*}{ RNA2 } & S68 & 1043 & 0.27 & 18.90 & GPP, Pigeonpea sterility mosaic emaravirus 2 (YP_009268865.1) & 90 & $5 \times 10^{-138}$ & 56.51 \\
\hline & S71 & 1024 & 0.26 & 18.45 & GPP, Pigeonpea sterility mosaic emaravirus 2 (YP_009268865.1) & 96 & $7 \times 10^{-153}$ & 61.49 \\
\hline RNA3 & S55 & 1177 & 0.30 & 24.46 & NC, Pea-associated emaravirus (QJX15716.1) & 80 & 0.0 & 99.05 \\
\hline RNA4 & S65 & 1070 & 0.27 & 16.79 & MP, Fig mosaic emaravirus (QBI22245.1) & 97 & 0.0 & 77.30 \\
\hline RNA5 & S164 & 635 & 0.16 & 13.04 & P6, Actinidia emaravirus 2 (QEE82891.1) & 78 & $2 \times 10^{-54}$ & 46.39 \\
\hline \multicolumn{9}{|c|}{ Fraxinus ornus } \\
\hline RNA2 & S146 & 1929 & 0.03 & 233.64 & GPP, Pigeonpea sterility mosaic emaravirus 2 (YP_009268865.1) & 95 & 0.0 & 59.90 \\
\hline RNA3 & S1644 & 1463 & 0.01 & 267.67 & NC, Pea-associated emaravirus (QJX15716.1) & 64 & 0.0 & 99.05 \\
\hline RNA4 & S81 & 1496 & 0.04 & 121.29 & MP, Fig mosaic emaravirus (QBI22245.1) & 72 & 0.0 & 77.29 \\
\hline RNA5 & S164 & 996 & 0.03 & 70.28 & P6, Actinidia emaravirus 2 (QEE82891.1) & 60 & $1 \times 10^{-65}$ & 47.50 \\
\hline
\end{tabular}


The sample E55270 from F. excelsior was analyzed further to obtain the complete sequence of all five genome segments of the novel virus identified in Fraxinus. The complete RNA1 was determined by assembling eight overlapping sequenced RT-PCR products, generated by eight specific primer sets (Table S1, Supplementary Information). The complete sequences of the RNA2-5 were determined by cloning and sequencing of full-length PCR products. No further RNA segments were amplified by this method, suggesting that the five RNAs represent the complete genome of the novel virus. The $2343^{\prime}$ terminal nucleotides of the RNA1 were confirmed by a tailing PCR. Likewise, the 13 nucleotides of the $3^{\prime}$ terminal of RNA2 could be confirmed, which were determined by the PDAP213 primer sequence. At least two individual clones were analyzed for sequence confirmation.

\subsection{Genome Organization of the Novel Virus Identified in Fraxinus spp. and Comparison with} Members of the Genus Emaravirus

The novel virus identified in F. excelsior (E55270) contained five RNA genome segments, each encoding a single open reading frame (ORF). Protein sequences encoded by ORFs of RNA1-RNA4 showed sequence identities and contained conserved domains characteristic for the viral replicase (RdRp, RNA1), a glycoprotein precursor (GPP, RNA2), the nucleocapsid protein (N, RNA3), and the movement protein (MP, RNA4) to certain members of the genus Emaravirus (Table 3 and Table S2, Supplementary Material).

Table 3. Amino acid sequence identities (\%) of RdRp, GPP, N, MP and P5, encoded by the RNA1-5 of the novel virus identified in a diseased Fraxinus excelsior (E55270, accession numbers: RNA1 OU46680, RNA2 OU466881, RNA3 OU466882, RNA4 OU466883, RNA5 OU466884), with corresponding proteins of classified and selected putative emaraviruses. Note: Accession numbers of putative and classified emaraviruses listed in supplementary information, Table S2.

\begin{tabular}{|c|c|c|c|c|c|}
\hline Virus & $\begin{array}{c}\text { RNA1 } \\
\text { (RdRp) }\end{array}$ & $\begin{array}{l}\text { RNA2 } \\
\text { (GPP) }\end{array}$ & $\begin{array}{c}\text { RNA3 } \\
\text { (N) }\end{array}$ & $\begin{array}{c}\text { RNA4 } \\
\text { (MP) }\end{array}$ & $\begin{array}{c}\text { RNA5 } \\
\text { (P 26-28 kDa) }\end{array}$ \\
\hline $\mathrm{AcCRaV}$ & 48.7 & 39.5 & 35.6 & 29.0 & 10.8 (P5, $27 \mathrm{kDa})$ \\
\hline $\mathrm{AcV}-2$ & 77.9 & 54.7 & 73.1 & 73.6 & $42.4(\mathrm{P} 6,27 \mathrm{kDa})$ \\
\hline AsMaV & 71.6 & 53.8 & 57.2 & 65.0 & 34.4 (P28, $28 \mathrm{kDa})$ \\
\hline BLMaV & 68.4 & 50.6 & 59.1 & 56.1 & $28.7(\mathrm{P} 5,26 \mathrm{kDa})$ \\
\hline CjaV-1 & 25.5 & 19.1 & 16.4 & 10.2 & - \\
\hline CjaV-2 & 26.2 & 18.3 & 13.1 & 9.4 & - \\
\hline $\mathrm{CORaV}$ & 31.1 & 21.7 & 17.6 & 16.4 & - \\
\hline EMARaV & 49.1 & 36.5 & 34.8 & $28.2^{1}$ & $10.6(\mathrm{P} 4,27 \mathrm{kDa})^{2}$ \\
\hline FMV & 73.8 & 55.2 & 69.2 & 76.1 & 31.0 (P6, 26 kDa) \\
\hline HPWMoV & 30.3 & 21.6 & 15.1 & 16.5 & - \\
\hline JYMaV & 31.5 & 21.8 & 20.5 & 15.8 & - \\
\hline $\mathrm{LiCRaV}$ & 48.6 & 38.2 & 34.3 & 30.7 & 13.0 (P5, 26 kDa) \\
\hline MaMaV & 67.5 & 50.1 & 47.6 & 62.6 & 32.7 (P6, 27 kDa) \\
\hline PCLSaV & 28.0 & 14.2 & 14.8 & 9.2 & - \\
\hline PerMV & 25.3 & 18.4 & 16.3 & 10.2 & $7.5(\mathrm{P}, 27 \mathrm{kDa})$ \\
\hline PaEV & - & - & 99.0 & - & - \\
\hline PiVB & 71.0 & 53.6 & 57.7 & 69.8 & 30.7 (P6, 28 kDa) \\
\hline PPSMV-1 & 53.2 & 44.0 & 40.6 & 38.5 & 32.7 (P6, $27 \mathrm{kDa})$ \\
\hline PPSMV-2 & 73.4 & 58.2 & 71.1 & 73.4 & $32.3(\mathrm{P} 6,27 \mathrm{kDa})$ \\
\hline PVBV & 31.4 & 19.3 & 15.2 & 16.1 & - \\
\hline RLBV & 31.3 & 21.4 & 18.8 & 17.3 & - \\
\hline RRV & 68.3 & 52.7 & 59.8 & 59.8 & $28.9(\mathrm{P} 6 \mathrm{~b}, 27 \mathrm{kDa})$ \\
\hline RYRSaV & 48.2 & 40.5 & 35.8 & 30.2 & $11.6(\mathrm{P} 5,26 \mathrm{kDa})$ \\
\hline TiRSaV & 31.0 & 20.8 & 18.5 & 14.0 & - \\
\hline
\end{tabular}

${ }^{1}$ EMARaV RNA5 [28], ${ }^{2}$ EMARaV RNA4 [26].

The RNA1 was found to be 7031 nucleotides (nt) long, with a single ORF (6891 nucleotides, 2297 aa) between 45 and $6935 \mathrm{nt}$ in the positive sense (mRNA) encoding the viral RdRp. The $268 \mathrm{kDa}$ protein exhibited a highest sequence identity of $77.9 \%$ to the RdRp 
of AcV-2. The RNA2 is $2243 \mathrm{nt}$ in length, with a single ORF (1926 nt, $642 \mathrm{nt})$ between 57 and $1982 \mathrm{nt}$, encoding a $73 \mathrm{kDa}$ glycoprotein precursor (GPP). The GPP was found to have the highest similarity to the pigeon pea sterility mosaic virus -2 (PPSMV-2) GPP (58.2\%). The RNA3 is $1483 \mathrm{nt}$ long, with a single ORF (948 nt, 316 aa) between $104 \mathrm{nt}$ and $1051 \mathrm{nt}$, encoding a $35 \mathrm{kDa}$ nucleocapsid protein $(\mathrm{N})$. The $\mathrm{N}$ protein is $99 \%$ identical to the complementary P3 protein of the recently identified pea-associated emaravirus (PaEV) [39]. The RNA4 is $1518 \mathrm{nt}$ in length with a single ORF (1086 nt, 362 aa) between 83 and $1168 \mathrm{nt}$, thought to encode the movement protein (MP). The $41 \mathrm{kDa}$ protein was found to be $76.1 \%$ identical to the MP of FMV. The RNA5 is $1333 \mathrm{nt}$ in length, with a single ORF (696 nt, $232 \mathrm{aa}$ ) between 70 and $765 \mathrm{nt}$. The function of the $26 \mathrm{kDa}$ protein remains unknown. However, blastx revealed similarities to other undetermined proteins, of classified emaraviruses, including AcV-2 P6 (42.4\%) and AsMaV (34.4\%).

The $5^{\prime}$ and $3^{\prime}$ termini of all five identified genome segments are conserved and show high complementary to each other. Therefore, genome segments may be capable of circularization by forming a panhandle structure through hybridization of the terminal sequences. However, the length of the terminal complementarity region varies in the different genome segments. The first 13 nucleotides seem to be strictly conserved in all RNAs, while complementarity of RNA1 extends to the $205^{\prime}$ and $3^{\prime}$ terminal nucleotides. The terminal complementarity regions of RNA2, RNA4 and RNA5 are $19 \mathrm{nt}$ long, while in RNA3 only a stretch of 17 terminal nts are fully complementary to each other (Figure S1, Supplementary Information).

Due to the current species demarcation criteria established by the ICTV [23] of more than $25 \%$ sequence divergence in RNA1-RNA3 encoded proteins of emaraviruses (RdRP, GPP, N), we consider the novel virus identified in diseased Fraxinus to be a distinct species within the genus. Due to the prominent leaf-narrowing symptom frequently observed, the name ash shoestring-associated virus $(\mathrm{ASaV})$ is proposed. The complete genome organization of ASaV is shown in Figure 2 and the complete RNA1-5 sequences were deposited in the ENA database under the accession numbers OU466880-OU466884, respectively.

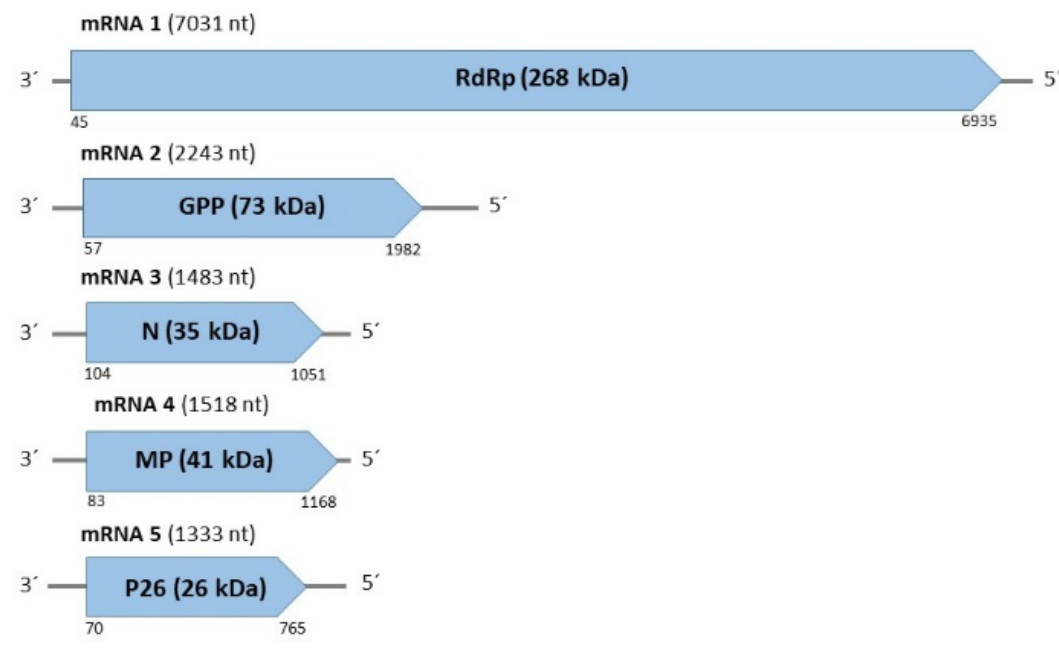

Figure 2. Genome organization of ash shoestring-associated virus (ASaV) identified in Fraxinus spp. The five known genome segments of the single-stranded negative-sense RNA virus are schematically displayed as mRNA with the total length shown in brackets (nt). Arrows depict the open reading frames (ORF) with the first and last nucleotide positions annotated below. The functions of the encoded proteins-RdRp (viral replicase), GPP (glycoprotein precursor), N (nucleocapsid protein), MP (movement protein), P26 (function unknown)-along with their molecular mass are also shown.

Phylogenetic trees based on amino acid (aa) alignments of the RNA1 encoded RdRp and the RNA3 encoded N protein were calculated for the ASaV variants identified in F. excelsior (E55270) and F. ornus (HTS data) and selected putative and established emaraviruses [27]. The phylogenetic relationships between the selected viruses, shown in 
Figure 3, exhibit four distinct subgroups A, B, C and D. Viruses in subgroups A and B are more closely related, sharing a common origin. The subgroups $C$ and $D$ are more distantly related. The RNA1 and RNA3 predicted proteins of ASaV were found to consistently cluster in subgroup A, together with those of classified emaraviruses including AcV-2, FMV and PPSMV-2. The trees also confirm the high sequences identities between the ASaV variants identified in F. excelsior and F. ornus, with both occupying a single terminal clade. The close phylogenetic relationships depicted therefore support the proposal of ASaV being a new, distinct member of the genus Emaravirus.

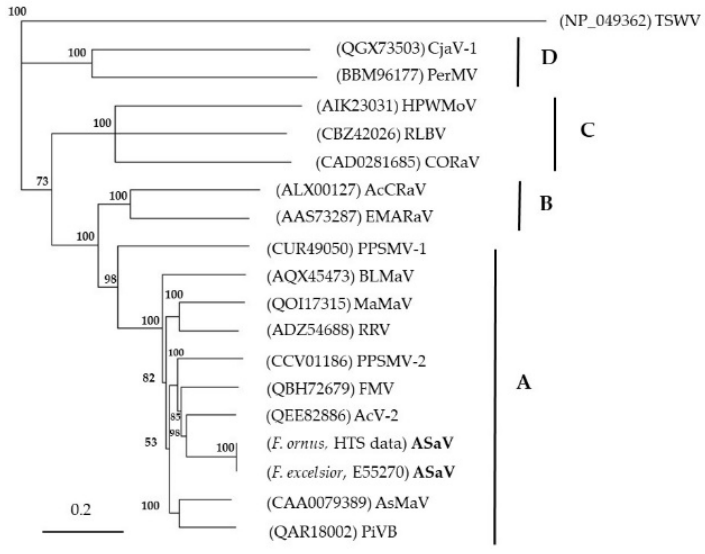

(a)

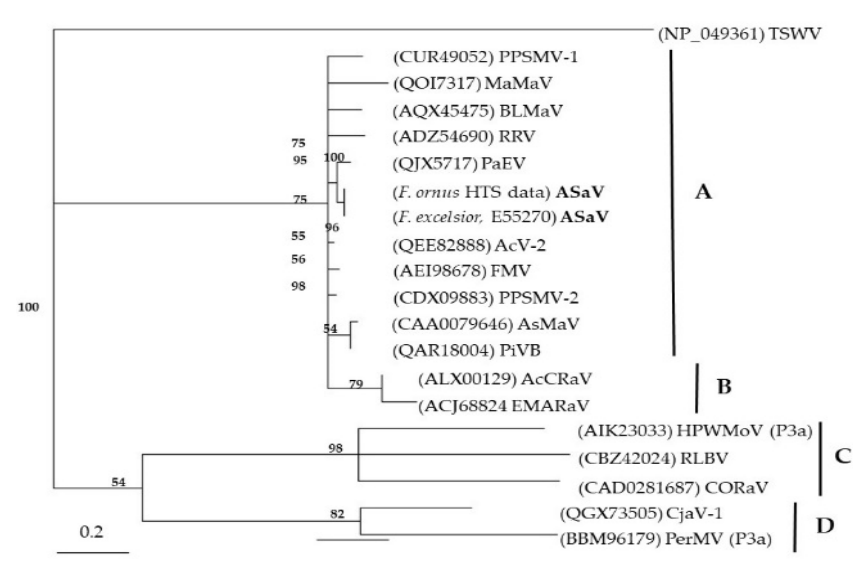

(b)

Figure 3. Phylogenetic placement of ash shoestring-associated virus (ASaV) based on RdRp (a) and N (b) amino acid sequences from F. excelsior (E55270) and F. ornus (HTS data) and corresponding sequences of selected putative and classified emaraviruses: actinidia chlorotic ringspot-associated virus (AcCRaV), blackberry leaf mottle-associated virus (BLMaV), European mountain ash ringspot-associated virus (EMARaV), fig mosaic virus (FMV), High Plains wheat mosaic virus (HPWMoV), pea-associated emaravirus (PaEV), pigeonpea sterility mosaic virus 1 and 2 (PPSMV-1 and PPSMV-2), pistacia virus $B(P i V B)$, raspberry leaf blotch virus (RLBV), rose rosette virus (RRV), actinidia virus 2 (AcEV-2), aspen mosaicassociated virus (AsMaV), camellia japonica-associated virus 1 (CjaV-1), perilla mosaic virus (PerMV). Branches report numbers that represent statistical support based on bootstrap analysis (1000 replicates). Tomato spotted wilt virus (TSWV, Orthotospovirus) was used as an outgroup species. Subgroups of emaraviruses are indicated by dashes with the letters A, B, C, and D, respectively.

\subsection{Establishment of a Virus Specific RT-PCR Detection}

We tested six segment-specific primer sets (Table 1 ) targeting the RNA1-5 to detect the putative novel emaravirus ASaV by RT-PCR. The suitability and specificity of the detection method was evaluated using total RNA extracted from 11 symptomatic and four asymptomatic $F$. excelsior leaves and four additional leaf samples infected by the putative and established emaraviruses, i.e., CORaV-infected oak, MaMaV-infected maple, AsMaVinfected aspen, and FMV-infected Figure ASaV genome segments RNA1-RNA5 were detectable by all six developed primer pairs in F. excelsior leaf material showing chlorotic ringspots and curling or shoestring symptoms (Figure 4, track 4, 5, 8). However, the RNA1-specific primer set S50-1081F/S294-160R also amplified a fragment of the expected size $289 \mathrm{bp}$ from the MaMaV-infected maple (A. pseudoplatanus; Figure 4, track 2) and from the FMV-infected fig (Ficus carica) (Figure 4, track 6) samples in RT-PCR. Additionally, the primer pair targeting RNA3 generated a weak amplification product of the expected size (342 bp) from the MaMaV-infected sample. The other primer sets were found to have a high specificity for ASaV detection by RT-PCR, with segment-specific primer sets amplifying the expected $425 \mathrm{bp}$ fragment of the RNA1, $243 \mathrm{bp}$ of the RNA2, $498 \mathrm{bp}$ of the RNA4 and $401 \mathrm{bp}$ of the RNA6 in infected ash only. Direct Sanger-sequencing of generated PCR products from both directions confirmed the respective virus species to be present in the investigated samples (data not shown). 


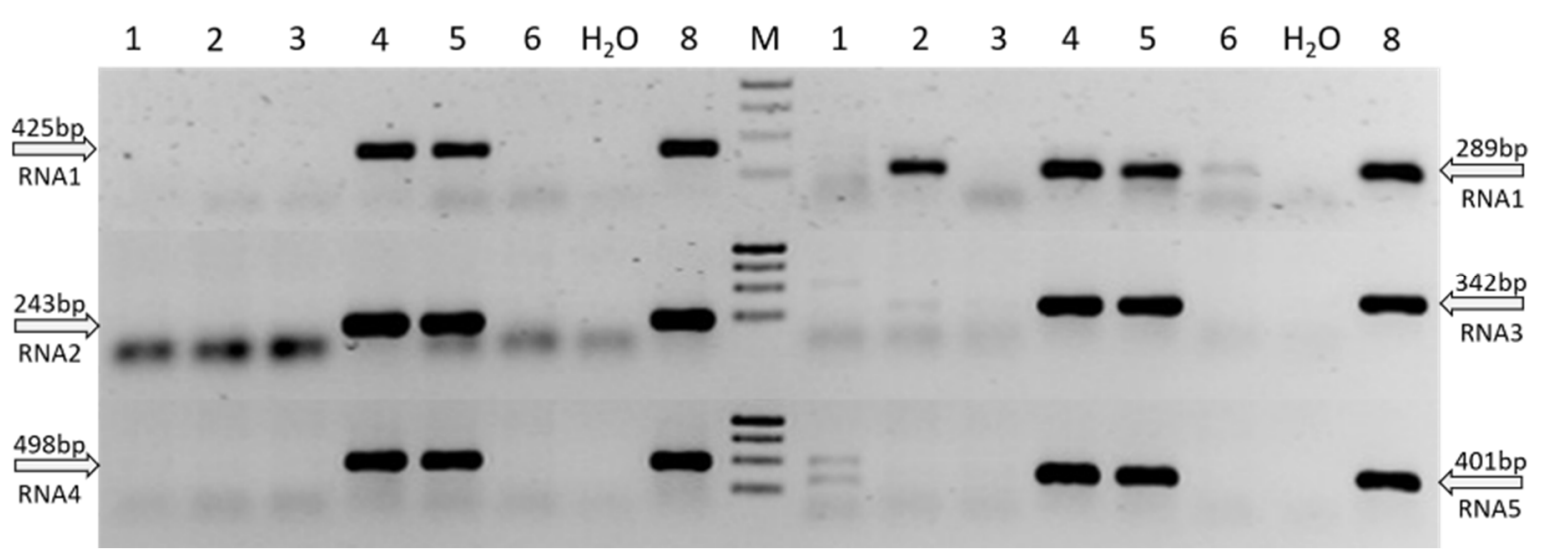

Figure 4. Detection of the five genomic RNAs of the putative novel emaravirus ASaV identified in Fraxinus spp. By RT-PCR using segment-specific primer sets in different leaf samples. (1) CORaV-infected common oak (2) MaMaV-infected maple; (3) AsMaV-infected aspen (4) E55269 and (5) E55270 F. excelsior exhibiting chlorotic ringspots and shoestring of leaves, Basel;

(6) FMV-infected fig; (8) = E55268 F. excelsior, Basel; $\mathrm{H}_{2} \mathrm{O}=$ non-template control (NTC).

\subsection{Geographical Distribution of ASaV and Association with Disease Symptoms}

Following its discovery in 2016, further infections of ASaV in F. excelsior were confirmed in Switzerland (Basel) and at new locations discovered in Crans Montana (Switzerland), Southern Sweden (Dalby Söderskog, Sigtuna, Bromma, Vreta, Krusenstern Herrgard, Hällekis Blomberg and Västerplana), and Germany (Berlin, Hamburg). Infections in the second host species, F. ornus, were also found in Germany (Hamburg), including trees at a local tree nursery and Northern Italy (Bolzano). Sample location, host species and ASaV detection are summarized in Figure 5 and Table 4.

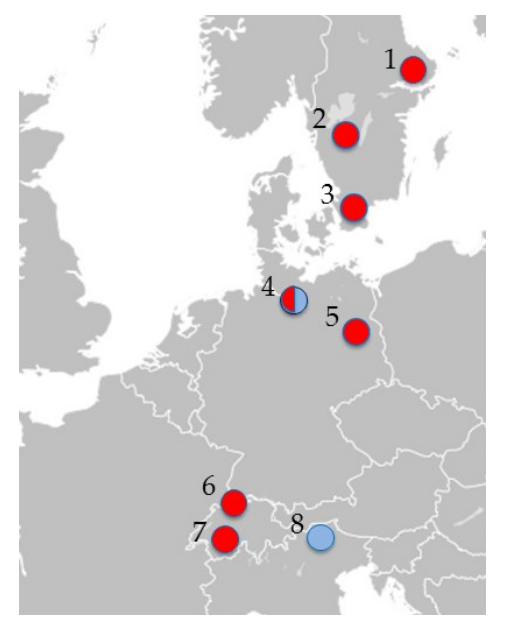

Figure 5. Current known distribution of putative emaravirus ash shoestring-associated virus (ASaV) in diseased Fraxinus excelsior and F. ornus. Key: F. excelsior: red, F. ornus: blue. 1 = Sigtuna, Bromma, Vreta, Krusenstern-Herrgard, Sweden, 2 = Hällekis Blomberg, Västerplana, Sweden, 3 = Dalby Söderskog, Sweden, 4 = Hamburg, Germany, 5 = Berlin, Germany, $6=$ Basel, Switzerland, 7 = Crans Montana, Switzerland, 8 = Bolzano, Italy.

Fraxinus samples collected during the vegetation periods from 2016 to 2019 displayed various suspected virus symptoms, including chlorotic ringspots, line pattern, checking and a range of leaf deformations, including curling and a narrowing of the leaflets termed shoestring. Figure 1 shows a selection of documented symptoms. In total, 52 F. excelsior and 57 F. ornus samples were tested by RT-PCR applying ASaV specific primer sets. The RNA3-5 primer sets were found to be most reliable. ASaV infections were confirmed by Sanger sequencing of PCR products (data not shown). Of 41 symptomatic F. excelsior 
samples, 37 (90\%) were found to be infected with ASaV. ASaV was also detected in 44 of 45 $(98 \%)$ symptomatic F. ornus samples (Table 4).

Table 4. Detection of putative emaravirus ash shoestring-associated virus (ASaV) in symptomatic and asymptomatic ash samples, without suspected virus symptoms, collected in 2016-2019 at locations across Europe.

\begin{tabular}{|c|c|c|c|c|}
\hline Location & Host Species & Samples & $\begin{array}{c}\text { Symptomatic/ASaV } \\
\text { Infected }\end{array}$ & $\begin{array}{c}\text { Asymptomatic/ASaV } \\
\text { Infected }\end{array}$ \\
\hline \multirow{2}{*}{ Germany $^{1}$} & F. excelsior & 5 & $5 / 4$ & - \\
\hline & F. ornus & 44 & $34 / 34$ & $10 / 1$ \\
\hline Germany $^{2}$ & F. ornus & 11 & $9 / 9$ & $2 / 2$ \\
\hline Italy & F. ornus & 2 & $2 / 1$ & - \\
\hline Sweden & F. excelsior & 39 & $29 / 26$ & $10 / 6$ \\
\hline Switzerland & F. excelsior & 8 & $6 / 6$ & $2 / 0$ \\
\hline \multirow{3}{*}{ Total } & F. excelsior & 52 & $40 / 36(90 \%)$ & $12 / 6(50 \%)$ \\
\hline & F. ornus & 57 & $45 / 44(98 \%)$ & $12 / 3(25 \%)$ \\
\hline & & 109 & $85 / 80(94 \%)$ & $24 / 9(38 \%)$ \\
\hline
\end{tabular}

${ }^{1}$ Street trees, ${ }^{2}$ tree nursery.

ASaV was also detectable in 6 of the $12(50 \%)$ asymptomatic F. excelsior samples and 3 of the 12 (25\%) samples from F. ornus with no observable disease symptoms. Our results show a strong correlation between suspected virus symptoms and ASaV infection in Fraxinus spp. ASaV was detected in $94 \%$ of the symptomatic samples overall, including all 21 samples displaying the shoestring symptom. The current known geographical range of ASaV extends across Northern and central Europe, from Southern Sweden in the north to Northern Italy in the south (Figure 5).

\subsection{Genetic Variability of ASaV Based on Partial Sequences}

A total of 118 partial ASaV PCR amplicons (RNA3 = 52, RNA4 = 17, RNA5 = 49) from infected F. excelsior and F. ornus were analyzed by pairwise sequence comparisons to assess genetic variability. All partial sequences lie within the coding region of the respective genome segment. Genetic distances calculated in MEGA-X are listed in Table 5.

Table 5. Comparison of genetic distances of ASaV RNA3, RNA4 and RNA5 partial nucleotide and amino acid sequences. Pairwise comparisons conducted on all partial sequences for each genome segment (F. excelsior, F. ornus) and for sequences originating from each host species separately (F. excelsior or F. ornus).

\begin{tabular}{|c|c|c|c|c|c|c|c|c|c|c|c|c|}
\hline $\begin{array}{c}\text { Host Species and } \\
\text { Genome } \\
\text { Segment }\end{array}$ & RNA & $\mathrm{n}^{1}$ & $\mathrm{Nt}^{2}$ & $\operatorname{Min}^{3}$ & $\operatorname{Max}^{3}$ & Mean & SEM $^{5}$ & aa & $\operatorname{Min}^{4}$ & $\operatorname{Max}^{4}$ & Mean & SEM $^{5}$ \\
\hline F. excelsior, F. ornus & \multirow{3}{*}{3} & 52 & \multirow{3}{*}{297} & 0 & 0.096 & 0.030 & 0.001 & \multirow{3}{*}{99} & 0 & 0.063 & 0.012 & 0.001 \\
\hline F. excelsior & & 18 & & 0 & 0.088 & 0.031 & 0.002 & & 0 & 0.063 & 0.011 & 0.002 \\
\hline F. ornus & & 34 & & 0 & 0.089 & 0.025 & 0.001 & & 0 & 0.063 & 0.012 & 0.001 \\
\hline F. excelsior, F. ornus & \multirow{3}{*}{4} & 17 & \multirow{3}{*}{453} & 0 & 0.062 & 0.025 & 0.001 & \multirow{3}{*}{151} & 0 & 0.034 & 0.004 & 0.001 \\
\hline F. excelsior & & 10 & & 0 & 0.055 & 0.026 & 0.003 & & 0 & 0.034 & 0.007 & 0.002 \\
\hline F. ornus & & 7 & & 0.002 & 0.044 & 0.025 & 0.003 & & 0 & 0 & 0 & 0 \\
\hline F. excelsior, F. ornus & \multirow{3}{*}{5} & 49 & \multirow{3}{*}{357} & 0 & 0.086 & 0.039 & 0.001 & \multirow{3}{*}{119} & 0 & 0.107 & 0.040 & 0.001 \\
\hline F. excelsior & & 17 & & 0 & 0.072 & 0.027 & 0.002 & & 0 & 0.097 & 0.033 & 0.002 \\
\hline F. ornus & & 32 & & 0 & 0.086 & 0.036 & 0.001 & & 0 & 0.106 & 0.033 & 0.002 \\
\hline
\end{tabular}

${ }^{1}$ Number of sequences analyzed; ${ }^{2}$ Fragment length excluding primers; ${ }^{3}$ Genetic distance calculated by maximum composite likelihood model implemented in Mega-X; ${ }^{\prime}$ Genetic distance calculated by equal input model implemented in Mega-X; ${ }^{5}$ Standard error of the mean.

Results demonstrate a high level of conservation of partial sequences at both the nucleotide (nt) and amino acid (aa) level, with mean genetic distances ranging from 0.025 
0.039 (standard error 0.001-0.003) and 0-0.04 (standard error 0-0.002) at the nt and aa level, respectively. The results of this first variability analysis indicated there is no correlation between genetic variability and geographical location or ASaV host species.

\subsection{Visualization of Double-Membrane Bodies in Virus-Infected Tissues}

In ultrathin sections of symptomatic ash leaf tissue, we found double-membrane bodies (DMBs), with an approximate diameter of 70-80 nm, which were associated with the smooth endoplasmatic reticulum located in the cytoplasm of mesophyll cells (Figure 6, white arrows). These DMBs are typically found in plant cells infected by emaraviruses [24] and we could observe them only in ASaV-infected leaf material but never in non-symptomatic ash leaves. This further supports the close association of the novel putative emaravirus $\mathrm{ASaV}$ with the chlorotic ringspots, curling and shoestring symptoms of leaves of diseased ash trees.
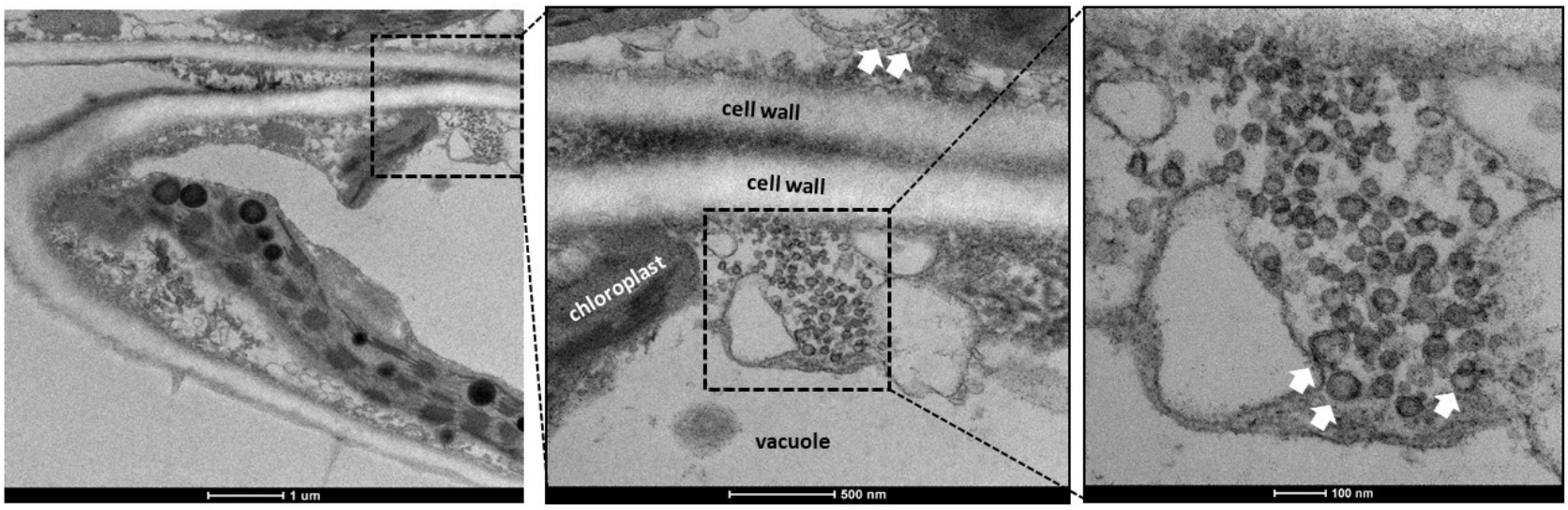

Figure 6. Thin section of mesophyll cells of a Fraxinus excelsior leaf exhibiting chlorotic ringspots and chloroses infected with the novel emaravirus as confirmed by virus-specific RT-PCR. White arrows indicate spherical particles (doublemembrane bodies, DMB) of different sizes (70-80 nm in diameter) typically associated with emaravirus-diseased leaf tissues. Squares indicate sections enlarged in the respective picture to the right.

\section{Discussion}

We identified a novel plant virus infecting European ash (Fraxinus excelsior) and manna ash (F. ornus) across Europe. Infected trees displayed symptoms including chlorotic ringspots, mottle, line pattern and leaf deformations of curling and shoestring. The virus is proposed as being a new member of the plant virus genus Emaravirus (Order: Bunyavirales; Family: Fimoviridae) [24], fulfilling established criteria for classification to the genus [23]: (i) A multipartite genome of at least four negative-sense single-stranded RNA segments each with a single open reading frame (ORF) encoding one protein. (ii) A significant homology of these proteins to the viral replicase (RdRP, RNA1), a glycoprotein precursor (GPP, RNA2), a nucleocapsid protein (N, RNA3) and a putative movement protein (MP, RNA4) of other recognized emaraviruses. (iii) Genome segments possessing conserved, complementary terminal nucleotide sequences; and (iv) the presence of spherical doublemembrane bodies (DMBs) with an approximate diameter of 70-80 $\mathrm{nm}$. The tentative name ash shoestring-associated virus (ASaV) is proposed for the novel emaravirus, after the most prominent symptom observed in diseased ash.

We identified five RNA genome segments (RNA1-5) of the novel virus in both affected ash species by HTS in combination with full-length PCR and Sanger sequencing and could attribute them to the putative emaravirus $\mathrm{ASaV}$. The sequence divergence of the five $\mathrm{ASaV}$ encoded proteins to the analogous proteins of other emaraviruses known to date clearly demonstrates the novel virus $\mathrm{ASaV}$ as being a separate species. Despite the fact that the divergence of $\mathrm{ASaV}$ encoded proteins is less than $25 \%$, when compared to the divergence of respective proteins of different members of the genus, this applies only to 
one of the respective protein sequences (RdRp, GPP, N), which are considered as relevant for species demarcation on a molecular level [23]. When comparing the ASaV encoded protein sequences to AcV2, only the RdRp shows identity above $75 \%$, while the other four encoded proteins (GPP, N, MP, P26) exhibit diversities above $25 \%$ to the respective homologs. In the case of the putative $\mathrm{N}$ protein of $\mathrm{ASaV}$, the aa sequence is nearly identical with the P3 of PaEV, suggesting that the emaravirus identified in pea may be the same as the novel virus we identified in ash. However, as RdRp, GPP, and MP sequences of $\mathrm{PaEV}$ are not available in the databases to date, this cannot be ascertained. In any case, the putative ASaV GPP and P26 demonstrate a diversity greater than 25\%, when compared to the analogous protein of any other emaravirus. Therefore, the species demarcation criteria established for the genus Emaravirus [23] are fulfilled. Whether these five RNA segments represent the complete genome of $\mathrm{ASaV}$ remains to be clarified. Although all emaraviruses comprise of at least four core RNA segments, the number of additional genome segments is known to vary $[23,33]$ with the 10 of perilla mosaic-associated virus (PerMV) being the highest number known to date [40]. However, as the five RNA segments attributed to AsaV were identified in two HTS datasets from pooled F. excelsior and F. ornus and also additionally by full-length RT-PCR, our results strongly suggest that we determined the complete genome of AsaV.

The fifth RNA5 encoded protein of AsaV was found to be homologous to a group of similar-sized, non-structural emaravirus proteins, designated P26-P28 according to their size (26-28 kDa), as described by von Bargen et al. [22]. The function and importance of these analogous proteins in the lifecycle of these emaraviruses, however, remains elusive. A specific interaction with host or vector proteins, or a role in virus pathogenicity has previously been speculated for such unknown proteins [33,41]. Viral suppressors of host RNA silencing mechanisms, for example, are well documented in other plant viruses [42,43], including the emaravirus High Plains wheat mosaic virus (HPWMoV), in which the P8 was reported to have suppressor activity [44,45]. However, no significant homology of the ASaV P26 was found to this protein.

Phylogenetic analyses based on amino acid alignments of the RdRp and N proteins of $\mathrm{ASaV}$ and selected emaraviruses revealed cladograms with four distinct subgroups (A, B, $\mathrm{C}$ and D), whereby ASaV consistently clustered in subgroup A. This not only corroborates the cumulative findings of previous emaravirus studies [21,22], but also confirms ASaV to be a new distinct emaravirus species, being to the best of our knowledge the first to have been detected in Fraxinus spp. Surprisingly, the N protein (RNA3) of ASaV was found to be nearly identical (99\%) to that of the recently discovered pea-associated emaravirus (PaEV) which infects green peas (Pisum sativum L.) [39]. This raises the question as to whether both viruses are in fact the same species. With the exception of mechanical transmission of emaraviruses occurring under experimental conditions [46-48], emaraviruses have largely been found to infect a single host or relatively few, closely related host species. Although a natural infection of both ash and peas would therefore seem unlikely, it would raise new epidemiological questions, if this were the case. However, as only the RNA3 of PaEV is currently available in the databases for analysis, the characterization of further PaEV genome segments is necessary to determine the phylogenetic relationship of both viruses.

$3^{\prime}$ terminal ends of the RNA1 and RNA2 were confirmed by tailing PCR as being the same as those generated by the genus specific PDAP213 primer [33]. The remaining terminal ends of ASaV are still to be confirmed. Possible explanations for the difficulties experienced in amplifying particular termini by this method may include an unequal distribution of virus particles in the host plant, or low concentrations of RNA complementary to the genomic viral strands. Tatineni et al. [49] found that the concentrations of negative sense RNA were up to 20 times higher than those of sense viral RNA in HPWMoV infected samples. Rapid amplification of cDNA ends (RACE) [50,51] or inverse PCR methods [52] could be used as alternative methods in future studies to confirm remaining terminal sequences. 
During this study, a successful RT-PCR-based method was established for the detection of ASaV in Fraxinus spp., applying virus-specific primer sets targeting the five RNA segments. All primer pairs are located within the coding regions of each genome segment and comparable detection results for $\mathrm{ASaV}$ were achieved for all sets. The existence of more divergent $\mathrm{ASaV}$ variants, which may not be detected by these primer sets, cannot, however, be excluded due to the limited sequence information currently available. Tatineni et al. (2014) [49] demonstrated the existence of HPWMoV variants differing significantly in the identity of only a single genome segment. To avoid the possibility of false negative results, samples should therefore be tested by applying primer sets for at least two different genome segments, as suggested by McGavin et al. [47]. However, as a 5\% maximum nucleotide diversity was found between two ASaV variants, each identified in a different Fraxinus species, this suggests that the overall sequence variability of $\mathrm{ASaV}$ is not expected to be high.

A close association between the presence of $\mathrm{AsaV}$ and the described host symptoms could be demonstrated in F. excelsior and F. ornus, indicating the virus to be the probable causal agent. Symptoms of chlorotic ringspots, mottle and line pattern are typical of many other emaravirus infections, including rowan (Sorbus aucuparia L.) infected with European mountain ash ringspot-associated virus (EMARaV) $[3,26]$. Many emaravirusinfected plants are also known to suffer a general decline over time, often leading to their eventual death $[3,41,53]$. Although several ash trees displaying premature leaf loss and branch dieback were observed during field excursions, these symptoms were most likely attributed to the fungus Hymenoscyphus fraxineus responsible for the ash dieback disease. This remains to be determined for ASaV-infected ash.

Interestingly, a range of leaf deformations, from curling to a severe narrowing of the leaflets known as shoestring, were also found to be associated with the presence of the virus in ash. Although symptom severity is likely a function of the developmental stage of the host at the time of infection and length of infection, Kallinen et al. [54] reported that symptom severity in rowan was not correlated with the EMARaV titer, as might be expected if this were the case. Symptom expression in the infected rowan was also found to vary over consecutive seasons. Virus strain and virulence, tolerance of the host plant and even differences in environmental conditions are factors likely to affect symptom development. Despite the absence of further sequences of known viruses in HTS datasets, Koch postulates establishing a direct causal link between $\mathrm{ASaV}$ and the disease symptoms have yet to be fulfilled. The difficulty of isolating the necessary infectious emaravirus particles to achieve this is well known [24]. The use of infectious full-length ASaV clones or graft transmission studies, as outlined by von Bargen et al. [22] and Führling and Büttner [55], would provide conclusive evidence of $\mathrm{ASaV}$ as the cause of the disease in previously healthy host plants. $\mathrm{ASaV}$ was also detected in a number of trees displaying no observable symptoms, thus confirming a latent infection of F. excelsior and F. ornus. Latent emaravirus infections have been documented for a number of other emaraviruses, including rowan infected with EMARaV [54] and pear infected with pear chlorotic leaf spot associated virus (PCLSaV) [56]. It is currently unclear whether the infected ash lacking disease symptoms were simply sampled at an early stage of infection and may have exhibited ASaV-related symptoms at other timepoints over the vegetation period or whether they remained latent, with disease development possibly only being induced during the influence of additional abiotic or biotic stress factors, for instance fungal infections.

$\mathrm{ASaV}$ infections were found to be widespread across Europe, ranging from Southern Sweden in the north to Bolzano, Northern Italy in the south. The native habitat of both host Fraxinus species, however, extends much further than the investigated area covered in this study, which is particularly true for F. ornus, which is native to the Mediterranean region [6]. These preliminary findings suggest however that $\mathrm{ASaV}$ is likely to be present throughout its host's range. As other emaraviruses have been found to infect more than one host species, the possibility of ASaV infecting additional Fraxinus spp., including nonnative ornamental species such as the red ash (F. pennsylvanica), is possible. EMARaV, for 
example, is known to infect several closely related species and interspecies hybrids of the family Rosaceae [26,28,57-59]. A European-wide ASaV monitoring would most probably reveal a more extensive geographical distribution and additional host species of the novel virus $\mathrm{ASaV}$.

Preliminary sequence data based on partial RNA3, 4 and 5 sequences, suggest a high level of genetic identity of $\mathrm{ASaV}$ at both the nucleotide and the amino acid level. There also appears to be no correlation between genetic variability and either host species or geographical location of trees sampled. Although more extensive sequence data are required from future studies to confirm this observation, these first results are in line with the theory that RNA virus populations are generally genetically stable despite having a high potential for genetic diversity [60]. Biological properties of viruses such as host type and mode of transmission are thought to play an important role in shaping genetic diversity, with purifying selection pressure constraining the variability of proteins required for interactions between virus, host and vector $[54,60,61]$. High sequence identities between emaravirus variants at different locations or between different hosts have been documented in several studies. An identity of over $97.1 \%$ for EMARaV was reported by Grimova et al. [58] in different, closely-related hosts. With respect to geographical location, Roßbach et al. [62], von Bargen et al. (2013) [61] and Kallinen et al. [54] all reported a high level of sequence identity of EMARaV at locations across Northern Europe and Russia. Roßbach et al. [62] for example, found $95.3-100 \%$ nucleotide identities in the RNA3 coding region (944 nt) of 36 EMARaV variants across Northern Europe. Interestingly, the authors also identified a small number of EMARaV variants with notably lower sequence identities, an observation also documented in rose rosette virus (RRV) [53]. The evolutionary significance of comparably few divergent variants in a virus population remains to be investigated. Although other studies have demonstrated genetically distinct emaravirus populations, highly similar variants were also found at geographically distant locations $[63,64]$. Although three distinct FMV populations were identified, based on the analysis of partial RNA3 fragments (873 nt) of 53 virus variants worldwide, highly similar virus variants at geographically distant regions were also found [64]. It was suggested that the trading of plants, leading to the long-distance migration of particular virus variants, may give rise to such observations [64]. The detection of $\mathrm{ASaV}$ at a tree nursery in our study indicates that the trading of ash trees could play an important role in determining genetic variability, but also in aiding the spread of the virus in general.

The increasing use of HTS technologies is revolutionizing the diagnosis and characterization of plant pathogens, particularly viruses [12,13]. Despite the new opportunities created by HTS for detecting novel viruses, an in-depth biological characterization remains essential for evaluating the significance and impact of these new species. This has led to a bottle neck in the evaluation of new species, and therefore a new standardized framework is required to solve this problem [65]. In our study, we report the discovery of a novel emaravirus in diseased Fraxinus spp. with the proposed name ash shoestring-associated virus $(\mathrm{ASaV})$ and provide the first important information to genome structure, phylogenetic placement and genetic variability. The establishment of a reliable RT-PCR-based detection method achieved in this study and its refinement in subsequent investigations will not only help unravel the epidemiology of ASaV, but will also aid the development of potential management strategies in the future, such as the testing and certification of plant material, ensuring healthy, virus-free ash for planting. A focus on virus infection will become particularly important in the selection of healthy trees for urban and forest plantings, with tolerance to the changing climatic conditions due to global warming. We have shown that $\mathrm{ASaV}$-infected ash trees are present in several European countries. They have been found in rural stands and forests such as the Swiss mountainous regions near Basel and Crans Montana but also have been propagated in tree nurseries and planted as street trees in urban sites in Germany and Sweden. Therefore, a European-wide ASaV monitoring in the future would most probably reveal a more extensive range as well as additional host species of the novel virus, thus allowing a better estimation of the impact of the identified 
novel virus and its role in the observed disease of investigated ash species. Although our observations of cauliflower gall growths on symptomatic ash strongly suggest Aceria fraxinivora to be a likely candidate for the natural transmission vector of $\mathrm{ASaV}$, this also remains to be confirmed.

Viruses are most likely to have an important role in the health of plants and forests [3], and a better understanding of their interaction with other stress factors affecting plants is essential. A loss of vitality and a predisposition of trees to other diseases resulting from viral infection is not only relevant for $\mathrm{ASaV}$ when selecting healthy ash trees, suitable for changing climatic conditions, but also with regard to the ash dieback disease, currently causing the decline in Fraxinus across Europe.

Supplementary Materials: The following are available online at https:/ / www.mdpi.com/article/10 $.3390 / \mathrm{f} 12111574 / \mathrm{s} 1$, Figure S1: Nucleotide sequences of the terminal complementarity regions of the five RNA genome segments of the novel emaravirus (E55270) infecting ash species are shown. Strictly conserved 13 terminal nucleotides (represented by the PDAP213 primer) are shown in bold. Sequences confirmed by tailing PCR are underlined. Table S1: Primer sets for the complete amplification of the ASaV RNA1 and tailing PCR for ASaV RNA1 and RNA2. Table S2: Accession numbers of putative and classified emaraviruse sequences used for amino acid sequence comparisons (Table 3) with the RdRp, GPP, N, MP and P5, encoded by the RNA1-5 of the novel virus ASaV identified in a diseased Fraxinus excelsior (E55270).

Author Contributions: Conceptualization, S.v.B.; Formal analysis, T.R.G., M.R. and S.v.B.; Methodology, T.R.G., M.T. and I.G.; Project administration, C.B.; Supervision, S.v.B.; Visualization, T.R.G., M.R. and S.v.B.; Writing-Original draft, T.R.G.; Writing-Review and editing, C.B. and S.v.B. All authors have read and agreed to the published version of the manuscript.

Funding: This research was funded by DEUTSCHE FORSCHUNGSGEMEINSCHAFT, grant number BU890/27-1 and BEHÖRDE FÜR WIRTSCHAFT UND INNOVATION, HAMBURG, grant number 734.650-004/014. Research collaboration was financially supported by EUROPEAN COOPERATION OF SCIENCE AND TECHNOLOGY (COST-DIVAS action FA1407). We acknowledge support by the GERMAN RESEARCH FOUNDATION (DFG) and the OPEN ACCESS PUBLICATION FUND of Humboldt-Universität zu Berlin.

Institutional Review Board Statement: Not applicable.

Informed Consent Statement: Not applicable.

Data Availability Statement: Identified scaffolds originating from the F. excelsior and F. ornus HTS datasets, which relate to emaraviral sequences as well as assembled sequences of the complete genome segments of the novel emaravirus, were deposited in the European Nucleotide Archive (ENA) and are available under the study number: PRJEB46740 (Accession numbers OU466864-OU466879).

Acknowledgments: We thank Gabriele Buddruss, Renate Junge, and Andrea Klinke for excellent technical assistance. Contribution to the monitoring of trees and sampling of leaf material for this study by Martina Bandte, Maria Landgraf, Florian Hüttner, and Kira Köpke as well as the support of our studies carried out in Sweden by Johanna Witzell (SLU Alnarp, Sweden) is kindly acknowledged. We are especially grateful to Katja Richert-Pöggeler (Julius Kühn-Institut, Braunschweig, Germany) providing the electron microscopic image of the gall mite Aceria fraxinivora displayed in Figure 1 and to Jean-Sebastien Reynard and Katia Gindro (Agroscope, Changins, Switzerland) for their valuable contribution to this study by conducting the electron microscopic studies of thin sections of ash leaf tissue.

Conflicts of Interest: The authors declare no conflict of interest. The funders had no role in the design of the study; in the collection, analyses, or interpretation of data; in the writing of the manuscript, or in the decision to publish the results.

\section{References}

1. Schmelzer, K.; Schmelzer, E.S.; Schmidt, H. Viruskrankheiten und virusverdächtige Erscheinungen an Forstgehölzen. Arch. Forstwes. 1966, 5, 107-120.

2. Nienhaus, F.; Hamacher, J. Virus diseases of European ash. Allg. Forstz. 1990, 385-386. 
3. Büttner, C.; von Bargen, S.; Bandte, M.; Mühlbach, H.P. Forest diseases caused by viruses. In Infectious Forest Diseases; Gonthier, P., Nicolotti, G., Eds.; CAB International: Wallingford, UK, 2013; pp. 50-75.

4. Nienhaus, F.; Castello, J.D. Viruses in forest trees. Annu. Rev. Phytopathol. 1989, 27, 165-186. [CrossRef]

5. Enderle, R.; Stenlid, J.; Vasaitis, R. An overview of ash (Fraxinus spp.) and the ash dieback disease in Europe. CAB Rev. 2019, 14, 1-12. [CrossRef]

6. Caudullo, W.; de Rigo, D. Fraxinus ornus in Europe: Distribution, habitat, usage and threats. In The European Atlas of Forest Tree Species: Modelling, Data and Information on Forest Tree Species; De Rigo, D., Caudullo, G., Houston-Durrant, T., San-Miguel-Ayanz, J., Eds.; Publishing Office of the European Union: Luxemburg, 2016; pp. 100-101.

7. Beck, P.; Caudullo, W.; de Rigo, D. Fraxinus excelsior in Europe: Distribution, habitat, usage and threats. In The European Atlas of Forest Tree Species: Modelling, Data and Information on Forest Tree Species; De Rigo, D., Caudullo, G., Houston-Durrant, T., San-Miguel-Ayanz, J., Eds.; Publishing Office of the European Union: Luxemburg, 2016; pp. 98-99.

8. Dobrowolska, D.; Hein, S.; Oosterbaan, A.; Wagner, S.; Clark, J.; Skovsgaard, J.P. A review of European ash (Fraxinus excelsior L.): Implication for silviculture. Forestry 2011, 84, 133-148. [CrossRef]

9. “Klimabäume" Welche Arten Können in Zukunft Gepflanzt Werden? Available online: https://www.lwg.bayern.de/mam/cms0 6/landespflege/dateien/zukunft_klimabaeume.pdf (accessed on 12 July 2021).

10. Zukunftsbäume für Die Stadt. Available online: https://galk.de/arbeitskreise/stadtbaeume/themenuebersicht/zukunftsbaeumefuer-die-stadt (accessed on 12 July 2021).

11. Kirisits, T. Eschenpathogen Chalara fraxinea nun auch in Kärnten nachgewiesen. Forstsch. Aktuell 2008, 45, 28-30.

12. Wu, Q.; Ding, S.W.; Zhang, Y.; Zhu, S. Identification of viruses and viroids by next-generation sequencing and homologydependent and homology-independent algorithms. Ann. Rev. Phytopathol. 2015, 53, 425-444. [CrossRef] [PubMed]

13. Massart, S.; Olmos, A.; Jijakli, H.; Candresse, T. Current impact and future directions of high throughput sequencing in plant virus diagnostics. Virus Res. 2014, 188, 90-96. [CrossRef] [PubMed]

14. Zheng, Y.; Gao, S.; Padmanabhan, C.; Li, R.; Galvez, M.; Gutierrez, D.; Fuentes, S.; Ling, K.S.; Kreuze, J.; Fei, Z. VirusDetect: An automated pipeline for efficient virus discovery using deep sequencing of small RNAs. Virology 2017, 500, 130-138. [CrossRef] [PubMed]

15. Massart, S.; Chiumenti, M.; De Jonghe, K.; Glover, R.; Haegeman, A.; Koloniuk, I.; Komínek, P.; Kreuze, J.; Kutnjak, D.; Lotos, L.; et al. Virus Detection by High-Throughput Sequencing of Small RNAs: Large-Scale Performance Testing of Sequence Analysis Strategies. Phytopathology 2019, 109, 488-497. [CrossRef]

16. Villamor, D.E.V.; Ho, T.; Al Rwahnih, M.; Martin, R.R.; Tzanetakis, I.E. High throughput sequencing for plant virus detection and discovery. Phytopathology 2019, 109, 716-725. [CrossRef] [PubMed]

17. Rumbou, A.; Candresse, T.; Marais, A.; Theil, S.; Langer, J.; Jalkanen, R.; Büttner, C. A novel badnavirus discovered from Betula sp. affected by birch leaf-roll disease. PLoS ONE 2018, 13, e0193888. [CrossRef]

18. Rumbou, A.; Candresse, T.; Marais, A.; Svanella-Dumas, L.; Landgraf, M.; von Bargen, S.; Büttner, C. Unravelling the virome in birch: RNA-Seq reveals a complex of known and novel viruses. PLoS ONE 2020, 15, e0221834. [CrossRef] [PubMed]

19. Rehanek, M.; von Bargen, S.; Bandte, M.; Karlin, D.G.; Büttner, C. A novel emaravirus comprising five RNA segments is associated with ringspot disease in oak. Arch. Virol. 2021, 166, 987-990. [CrossRef] [PubMed]

20. Bandte, M.; Rehanek, M.; Leder, B.; von Bargen, S.; Büttner, C. Identification of an emaravirus in a common Oak (Quercus robur L.) Conservation seed orchard in germany: Implications for Oak health. Forests 2020, 11, 1174. [CrossRef]

21. Rumbou, A.; Candresse, T.; von Bargen, S.; Büttner, C. Next-Generation Sequencing Reveals a Novel Emaravirus in Diseased Maple Trees from a German Urban Forest. Front. Microbiol. 2021, 11, 621179. [CrossRef] [PubMed]

22. von Bargen, S.; Al Kubrusli, R.; Gaskin, T.; Fürl, S.; Hüttner, F.; Blystad, D.-R.; Karlin, D.G.; Jalkanen, R.; Büttner, C. Characterisation of a novel Emaravirus identified in mosaic-diseased Eurasian aspen (Populus tremula). Ann. App. Biol. 2020, 176, $210-222$. [CrossRef]

23. Elbeaino, T.; Digiaro, M.; Mielke-Ehret, N.; Muehlbach, H.P.; Martelli, G.P. ICTV Virus Taxonomy Profile: Fimoviridae. J. Gen. Virol. 2018, 99, 1478-1479. [CrossRef] [PubMed]

24. Mielke-Ehret, N.; Mühlbach, H.P. Emaravirus: A novel genus of multipartite, negative strand RNA plant viruses. Viruses 2012, 4 , 1515-1536. [CrossRef]

25. Kormelink, R.; Garcia, M.L.; Goodin, M.; Sasaya, T.; Haenni, A.L. Negative-strand RNA viruses: The plant-infecting counterparts. Virus Res. 2011, 162, 184-202. [CrossRef] [PubMed]

26. Mielke, N.; Muehlbach, H.P. A novel, multipartite, negative-strand RNA virus is associated with the ringspot disease of European mountain ash (Sorbus aucuparia L.). J. Gen. Virol. 2007, 88, 1337-1346. [CrossRef] [PubMed]

27. ICTV Taxonomy Release 2020. Available online: https:/ /talk.ictvonline.org/taxonomy (accessed on 6 July 2021).

28. von Bargen, S.; Dieckmann, H.L.; Candresse, T.; Mühlbach, H.-P.; Roßbach, J.; Büttner, C. Determination of the complete genome sequence of European mountain ash ringspot-associated emaravirus from Sorbus intermedia reveals two additional genome segments. Arch. Virol. 2019, 164, 1937-1941. [CrossRef] [PubMed]

29. Walker, B.J.; Abeel, T.; Shea, T.; Priest, M.; Abouelliel, A.; Sakthikumar, S.; Cuomo, C.A.; Zeng, Q.; Wortman, J.; Young, S.K.; et al. Pilon: An integrated tool for comprehensive microbial variant detection and genome assembly improvement. PLoS ONE 2014, 9, e112963. [CrossRef] 
30. Boetzer, M.; Henkel, C.V.; Jansen, H.J.; Butler, D.; Pirovano, W. Scaffolding pre-assembled contigs using SSPACE. Bioinformatics 2011, 27, 578-579. [CrossRef]

31. Boetzer, M.; Pirovano, W. Toward almost closed genomes with GapFiller. Genome Biol. 2012, 13, R56. [CrossRef]

32. Hall, T.A. BioEdit: A user-friendly biological sequence alignment editor and analysis program for Windows 95/98/NT. Nucleic Acids Symp. Ser. 1999, 41, 95-98.

33. Di Bello, P.L.; Ho, T.; Tzanetakis, I.E. The evolution of emaraviruses is becoming more complex: Seven segments identified in the causal agent of Rose rosette disease. Virus Res. 2015, 210, 241-244. [CrossRef]

34. Edgar, R.C. MUSCLE: Multiple sequence alignment with high accuracy and high throughput. Nucleic Acids Res. 2004, 32, 1792-1797. [CrossRef] [PubMed]

35. Elbeaino, T.; Digiaro, M.; Alabdullah, A.; De Stradis, A.; Minafra, A.; Mielke, N.; Castellano, M.A.; Martelli, G.P. A multipartite single-stranded negative-sense RNA virus is the putative agent of fig mosaic disease. J. Gen. Virol. 2009, 90, 1281-1288. [CrossRef]

36. Menzel, W.; Jelkmann, W.; Maiss, E. Detection of four apple viruses by multiplex RT-PCR assays with coamplification of plant mRNA as internal control. J. Virol. Methods 2002, 99, 81-92. [CrossRef]

37. Kumar, S.; Stecher, G.; Li, M.; Knyaz, C.; Tamura, K. MEGA X: Molecular evolutionary genetics analysis across computing platforms. Mol. Biol. Evol. 2018, 35, 1547-1549. [CrossRef] [PubMed]

38. Reynolds, E.S. Use of lead citrate at high pH as an electron-opaque stain in electron microscopy. J. Cell Biol. 1963, 17, 208-209. [CrossRef] [PubMed]

39. Gaafar, Y.Z.; Herz, K.; Hartrick, J.; Fletcher, J.; Blouin, A.G.; MacDiarmid, R.; Ziebell, H. Investigating the Pea Virome in Germany-Old Friends and New Players in the Field. Front. Microbiol. 2020, 11, 583242. [CrossRef] [PubMed]

40. Kubota, K.; Usugi, T.; Tomitaka, Y.; Shimomoto, Y.; Takeuchi, S.; Kadono, F.; Yanagisawa, H.; Chiaki, Y.; Tsuda, S. Perilla Mosaic Virus Is a Highly Divergent Emaravirus Transmitted by Shevtchenkella sp. (Acari: Eriophyidae). Phytopathology 2020, 110, 1352-1361. [CrossRef]

41. Hassan, M.; Di Bello, P.L.; Keller, K.E.; Martin, R.R.; Sabanadzovic, S.; Tzanetakis, I.E. A new, widespread emaravirus discovered in blackberry. Virus Res. 2017, 235, 1-5. [CrossRef]

42. Csorba, T.; Burgyan, J. Antiviral Silencing and Suppression of Gene Silencing in Plants. In Current Research Topics in Plant Virology; Wang, A., Zhou, X., Eds.; Springer: Berlin/Heidelberg, Germany, 2016; pp. 1-33.

43. Pumplin, N.; Voinnet, O. RNA silencing suppression by plant pathogens: Defense, counter defense and counter-counter-defense. Nat. Rev. Microbiol. 2013, 11, 745-760. [CrossRef] [PubMed]

44. Gupta, A.K.; Hein, G.L.; Graybosch, R.A.; Tatineni, S. Octapartite negative-sense RNA genome of High Plains wheat mosaic virus encodes two suppressors of RNA silencing. Virology 2018, 518, 152-162. [CrossRef] [PubMed]

45. Gupta, A.K.; Hein, G.L.; Tatineni, S. P7 and P8 proteins of High Plains wheat mosaic virus, a negative-strand RNA virus, employ distinct mechanisms of RNA silencing suppression. Virology 2019, 535, 20-31. [CrossRef]

46. Olmedo-Velarde, A.; Park, A.C.; Sugano, J.; Uchida, J.Y.; Kawate, M.; Borth, W.B.; Hu, J.S.; Melzer, M.J. Characterization of Ti ringspot-associated virus, a novel emaravirus associated with an emerging ringspot disease of Cordyline fruticosa. Plant Dis. 2019, 103, 2345-2352. [CrossRef] [PubMed]

47. McGavin, W.J.; Mitchell, C.; Cock, P.J.A.; Wright, K.M.; MacFarlane, S.A. Raspberry leaf blotch virus, a putative new member of the genus Emaravirus, encodes a novel genomic RNA. J. Gen. Virol. 2012, 93, 430-437. [CrossRef]

48. Zheng, Y.; Navarro, B.; Wang, G.; Wang, Y.; Yang, Z.; Xu, W.; Zhu, C.; Wang, L.; Di Serio, F.; Hong, N. Actinidia chlorotic ringspot-associated virus: A novel emaravirus infecting kiwifruit plants. Mol. Plant Pathol. 2017, 18, 569-581. [CrossRef] [PubMed]

49. Tatineni, S.; McMechan, A.J.; Wosula, E.N.; Wegulo, S.N.; Graybosch, R.A.; French, R.; Hein, G.L. An eriophyid mite-transmitted plant virus contains eight genomic RNA segments with unusual heterogeneity in the nucleocapsid protein. J. Virol. 2014, 88, 11834-11845. [CrossRef] [PubMed]

50. Scotto-Lavino, E.; Du, G.; Frohman, M.A. 3' end cDNA amplification using classic RACE. Nat. Protoc. 2006, 1, $2742-2745$. [CrossRef]

51. Scotto-Lavino, E.; Du, G.; Frohman, M.A. $5^{\prime}$ end cDNA amplification using classic RACE. Nat. Protoc. 2006, 1, $2555-2562$. [CrossRef] [PubMed]

52. Ochman, H.; Gerber, A.S.; Hartl, D.L. Genetic applications of an inverse polymerase chain reaction. Genetics 1988, 120, 621-623. [CrossRef]

53. Laney, A.G.; Keller, K.E.; Martin, R.R.; Tzanetakis, I.E. A discovery 70 years in the making: Characterization of the rose rosette virus. J. Gen. Virol. 2011, 92, 1727-1732. [CrossRef]

54. Kallinen, A.K.; Lindberg, I.L.; Tugume, A.K.; Valkonen, J.P. Detection, distribution, and genetic variability of European mountain ash ringspot-associated virus. Phytopathology 2009, 99, 344-352. [CrossRef]

55. Führling, M.; Büttner, C. Transmission experiments of viruses to woody seedlings (Quercus robur L. and Sorbus aucuparia L.) by grafting and mechanical inoculation. Eur. J. For. Path. 1995, 25, 129-135.

56. Liu, H.; Wang, G.; Yang, Z.; Wang, Y.; Zhang, Z.; Li, L.; Waqas, M.; Hong, N.; Liu, H.; Wang, G.; et al. Identification and Characterization of a Pear Chlorotic Leaf Spot-Associated Virus, a Novel Emaravirus Associated with a Severe Disease of Pear Trees in China. Plant Dis. 2021, 104, 2786-2798. [CrossRef] [PubMed] 
57. $\quad$ von Bargen, S.; Bandte, M.; Al Kubrusli, R.; Jalkanen, R.; Büttner, C. First report of European mountain ash ringspot-associated virus in Karpatiosorbus $x$ hybrida in Finland. New Dis. Rep. 2020, 42, 1.

58. Grimová, L.; Marek, M.; Konrady, M.; Ryšánek, P. Newly identified host range of European mountain ash ringspot-associated virus (EMARaV) and its distribution in the Czech Republic. For. Pathol. 2015, 45, 177-189. [CrossRef]

59. von Bargen, S.; Tischendorf, M.; Büttner, C. First report of European mountain ash ringspot-associated virus in serviceberry (Amelanchier spp.) in Germany. New Dis. Rep. 2018, 37, 19. [CrossRef]

60. García-Arenal, F.; Fraile, A.; Malpica, J.M. Variability and genetic structure of plant virus populations. Annu. Rev. Phytopathol. 2001, 39, 157-186. [CrossRef]

61. von Bargen, S.; Arndt, N.; Robel, J.; Jalkanen, R.; Büttner, C. Detection and genetic variability of European mountain ash ringspot-associated virus (EMARaV) in Sweden. For. Pathol. 2013, 43, 429-432. [CrossRef]

62. Roßbach, J.; Dieckmann, H.L.; Büttner, T.; Mühlbach, H.P.; von Bargen, S.; Büttner, C. Genetic Variability and Phylogeny of European mountain ash ringspot-associated virus RNA3 and RNA4. Forests 2015, 6, 4072-4087. [CrossRef]

63. Dong, L.; Lemmetty, A.; Latvala, S.; Samuilova, O.; Valkonen, J.P.T. Occurrence and genetic diversity of Raspberry leaf blotch virus (RLBV) infecting cultivated and wild Rubus species in Finland. Ann. Appl. Biol. 2016, 168, 122-132. [CrossRef]

64. Walia, J.J.; Willemsen, A.; Elci, E.; Caglayan, K.; Falk, B.W.; Rubio, L. Genetic variation and possible mechanisms driving the evolution of worldwide Fig mosaic virus isolates. Phytopathology 2014, 104, 108-114. [CrossRef] [PubMed]

65. Massart, S.; Candresse, T.; Gil, J.; Lacomme, C.; Predajna, L.; Ravnikar, M.; Reynard, J.-S.; Rumbou, A.; Saldarelli, P.; Škorić, D.; et al. A framework for the evaluation of biosecurity, commercial, regulatory, and scientific impacts of plant viruses and viroids identified by NGS technologies. Front. Microbiol. 2017, 8, 45. [CrossRef] [PubMed] 